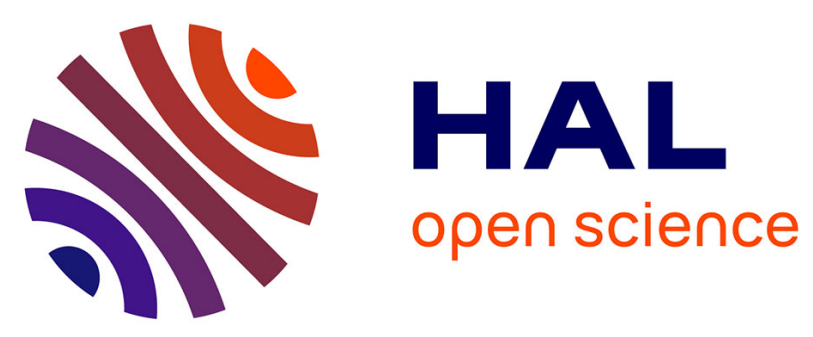

\title{
Radium-228 as a tracer of dissolved trace element inputs from the Peruvian continental margin
}

\author{
V. Sanial, L.E. Kipp, P.B. Henderson, P. van Beek, J.-L. Reyss, D.E. \\ Hammond, N.J. Hawco, M.A. Saito, J.A. Resing, P. Sedwick, et al.
}

\section{- To cite this version:}

V. Sanial, L.E. Kipp, P.B. Henderson, P. van Beek, J.-L. Reyss, et al.. Radium-228 as a tracer of dissolved trace element inputs from the Peruvian continental margin. Marine Chemistry, 2018, 201, pp. 20-34. 10.1016/j.marchem.2017.05.008 . hal-02007361

\section{HAL Id: hal-02007361 https://hal.science/hal-02007361}

Submitted on 10 Apr 2020

HAL is a multi-disciplinary open access archive for the deposit and dissemination of scientific research documents, whether they are published or not. The documents may come from teaching and research institutions in France or abroad, or from public or private research centers.
L'archive ouverte pluridisciplinaire HAL, est destinée au dépôt et à la diffusion de documents scientifiques de niveau recherche, publiés ou non, émanant des établissements d'enseignement et de recherche français ou étrangers, des laboratoires publics ou privés. 


\title{
Sanial, V., van Beek, P., Lansard, B., Souhaut, M., Kestenare, E., d'Ovidio, F., Zhou, M. and Blain, S.: Use of Ra isotopes to deduce rapid transfer of sediment-derived inputs off Kerguelen, Biogeosciences, 12(5), 1415-1430, doi:10.5194/bg-12-1415-2015, 2015.
}

\section{Radium-228 as a tracer of dissolved trace element inputs from the Peruvian continental margin}

\author{
V. Sanial ${ }^{\mathrm{a}, *}$, L.E. Kipp ${ }^{\mathrm{a}}$, P.B. Henderson ${ }^{\mathrm{a}}$, P. van Beek ${ }^{\mathrm{b}}$, J.-L. Reyss ${ }^{\mathrm{c}}$, D.E. Hammond ${ }^{\mathrm{d}}$, N.J. Hawco ${ }^{\mathrm{a}}$,

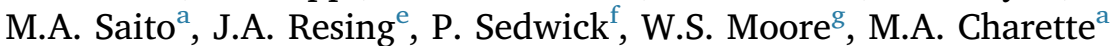 \\ a Department of Marine Chemistry and Geochemistry, Woods Hole Oceanographic Institution, Woods Hole, MA 02543, USA \\ ${ }^{\mathrm{b}}$ Laboratoire d'Etudes en Géophysique et Océanographie Spatiales (LEGOS), CNRS-CNES-IRD-UPS, Observatoire Midi Pyrénées, 31400 Toulouse, France \\ ${ }^{\mathrm{c}}$ Environnements, Dynamiques et Territoires de la Montagne (EDYTEM), Université de Savoie Mont Blanc, CNRS, 73373 Le Bouget du Lac, Cedex, France \\ d Department of Earth Sciences, University of Southern California, Los Angeles, CA 90089-0740, USA \\ e Joint Institute for the Study of the Atmosphere and the Ocean, NOAA-Pacific Marine Environmental Laboratory and the University of Washington, Seattle, WA, USA \\ ${ }^{f}$ Department of Ocean, Earth and Atmospheric Sciences, Old Dominion University, Norfolk, VA 23529, USA \\ ${ }^{g}$ Department of Earth and Ocean Sciences, University of South Carolina, Columbia, SC 29208, USA
}

\section{A R T I C L E I N F O}

\section{Keywords:}

Radium isotopes

Sediment inputs

Trace elements

GEOTRACES

\begin{abstract}
A B S T R A C T
Continental margins play a central role in the composition of seawater by being an important source of trace element essentials to the functioning of the ocean ecosystems. Here, we measured long-lived radium isotopes $\left({ }^{226} \mathrm{Ra},{ }^{228} \mathrm{Ra}\right)$ along a zonal transect at $12^{\circ} \mathrm{S}$ (US GEOTRACES GP16) in the eastern tropical South Pacific Ocean. We used ${ }^{228} \mathrm{Ra}$ to quantify the trace element and isotope (TEI) fluxes (DMn, DFe, and DCo) delivered from the Peruvian continental i) shelf and ii) slope. First, elevated ${ }^{228} \mathrm{Ra}$ activities were measured in surface water over the entire transect $(\sim 8500 \mathrm{~km})$, evidence that the continental shelf is an important source of sediment-derived TEIs not only to coastal areas, but to central Pacific Ocean waters. Modeled ${ }^{228} \mathrm{Ra}$ shelf fluxes combined with water column dissolved TEI ${ }^{228} \mathrm{Ra}$ ratios were used to quantify the shelf-ocean input rates (normalized to shelf-area) for $\mathrm{DMn}\left(3.3 \times 10^{3} \mu \mathrm{mol} \mathrm{m}^{-2} \mathrm{y}^{-1}\right)$, DFe $\left(1.5 \times 10^{3} \mu \mathrm{mol} \mathrm{m}^{-2} \mathrm{y}^{-1}\right)$, and DCo $\left(1.0 \times 10^{2} \mu \mathrm{mol} \mathrm{m}{ }^{-2} \mathrm{y}^{-1}\right)$. Second, co-occurring plumes of ${ }^{228} \mathrm{Ra}$, DFe, and DMn extended over $1800 \mathrm{~km}$ from the margin at 1000-2500 $\mathrm{m}$ depth, indicative of a continental slope sediment TEI input to the intermediate water column. The ${ }^{228} \mathrm{Ra}$ gradient allowed us to derive an effective horizontal eddy diffusion coefficient $\left(\mathrm{K}_{\mathrm{h}}\right)$ of $46 \mathrm{~m}^{2} \mathrm{~s}^{-1}$, which in turn permitted the calculation of slope sediment DMn $\left(6.4 \mu \mathrm{mol} \mathrm{m}^{-2} \mathrm{y}^{-1}\right)$ and DFe $\left(5.9 \times 10^{2} \mu \mathrm{mol} \mathrm{m}^{-2} \mathrm{y}^{-1}\right)$ fluxes based on their offshore concentration gradients. On the scale of the South Pacific continental margin between $0-20^{\circ} \mathrm{S}$, the DMn shelf flux is approximately 2-3 orders of magnitude higher than the slope flux, while the DFe shelf/slope flux is $\sim 3: 1$. Both shelf and slope sediment derived DMn was transported over a significant distance towards the ocean interior, while DFe concentration gradients were steep, consistent with longer water column residence time for DMn as compared to DFe in marine systems. These findings highlight the importance of considering the continental slope-ocean boundary in the oceanic budgets of biologically-important trace elements.
\end{abstract}

\section{Introduction}

Continental margins, at the interface between land and ocean, play a central role in marine primary productivity through the supply of biologically-essential trace elements to the ocean. They comprise a shelf region with a gentle bathymetric gradient, and a much steeper slope area that extends to the deep ocean abyssal plain. In the eastern tropical South Pacific Ocean, the margin hosts a highly productive coastal upwelling system (Pennington et al., 2006) that drives high rates of primary production responsible for as much as $10 \%$ of the world's fish catch (Chavez et al., 2008). The upwelling is most intense between $4^{\circ} \mathrm{S}$ and $16^{\circ} \mathrm{S}$. Though its strength may exhibit seasonal variability, it is a permanent feature due to persistent alongshore winds (Chavez et al., 2008). With high productivity comes intense respiration of sinking organic matter, which, combined with weak ocean ventilation, leads to the formation of an OMZ (oxygen minimum zone) (Karstensen et al., 2008), one of the most extensive OMZs in the world ocean (Paulmier and Ruiz-Pino, 2009). While upwelling supplies significant quantities of macronutrients, phytoplankton growth can be limited by the availability of the micronutrient iron

\footnotetext{
* Corresponding author.

E-mail address: vsanial@whoi.edu (V. Sanial).
} 
(Bruland et al., 2005; Hutchins et al., 2002).

Along the coastal margin, major sources of trace elements like iron include rivers (e.g. Viers et al., 2009), dust (e.g. Jickells et al., 2005), submarine groundwater discharge (SGD; e.g. Moore, 1996) and diffusion from sediments (e.g. Dale et al., 2015). Dust deposition, a major source of iron to the ocean, as well as riverine inputs, are relatively low in the eastern South Pacific (Jickells et al., 2005; Milliman and Farnsworth, 2011). This is partly because the Peru coastal region is characterized by relatively low precipitation (Scholl et al., 1970), and dust deposition decreases rapidly away from the coast (Albani et al., 2014). Sediments may be an important source of trace elements in this setting, though they only recently have been fully considered as a source term in ocean mass balances (Elrod et al., 2004; Jeandel et al., 2011; Moore and Braucher, 2008; Tagliabue et al., 2014; Windom et al., 2006).

The Peru OMZ impinges on the shelf and slope, which facilitates Fe (II) release from margin sediments into the overlying water column (Scholz et al., 2011). Thus, continental shelf sedimentary sources may be the primary source of iron that sustains the productivity of the Peru upwelling region (Johnson et al., 1999). The oxygen deficiency drives active biogeochemical cycles for many other trace elements, especially those that are redox sensitive (Codispoti et al., 2005). In particular, high concentrations of micronutrients such as dissolved cobalt (DCo) and manganese (DMn) have been observed in low oxygen waters (Hatta et al., 2015; Johnson et al., 1996; Noble et al., 2012) including in the Peru OMZ (Hawco et al., 2016; Resing et al., 2015).

Here, we use the naturally occurring radium isotopes ${ }^{226} \mathrm{Ra}\left(\mathrm{T}_{1}\right.$ / $\left.{ }_{2}=1600 \mathrm{y}\right)$ and ${ }^{228} \mathrm{Ra}\left(\mathrm{T}_{1 / 2}=5.75 \mathrm{y}\right)$ as tracers of trace element and isotope (TEI) inputs from the Peruvian continental margin. Radium isotopes are continuously produced through the decay of thorium isotopes in sediments. Because radium isotopes are mobile in seawater in contrast to their thorium parents, advective input from coastal aquifers (Moore, 1996) and diffusion from marine sediments are the two major pathways by which Ra enters the ocean (Koczy, 1958; Kaufman et al., 1973; Moore, 1969a, 1969b). In this way, Ra isotopes help fulfill a central goal of the international GEOTRACES program: to identify processes and quantify fluxes that control the distribution of TEIs at the ocean boundaries. The distribution of ${ }^{228} \mathrm{Ra}$ along a zonal section off Peru is used to identify to what extent the dissolved TEI enrichments, with a focus on $\mathrm{Mn}, \mathrm{Co}$, and $\mathrm{Fe}$, are derived from margin sedimentary sources. We also use ${ }^{228} \mathrm{Ra}$ as a flux gauge to quantify TEI inputs from the Peruvian continental margin, including the shelf and slope. First, we describe the distributions of ${ }^{226} \mathrm{Ra}$ and ${ }^{228} \mathrm{Ra}$ over a zonal transect between Peru and Tahiti. Then, we present estimations of ${ }^{228} \mathrm{Ra}$ slope and shelf fluxes. Finally, we combine the distributions of $\mathrm{Mn}$, Co, and $\mathrm{Fe}$ with an application of ${ }^{228} \mathrm{Ra}$ as a flux gauge to estimate the shelf and slope benthic fluxes of these TEIs.

\section{Methods}

Seawater samples for Ra isotope analysis were collected onboard the $R / V$ Thomas $G$. Thomson during the U.S. GEOTRACES Eastern Pacific Zonal Transect (GP16; Oct 26th-Dec 23rd 2013; PI: C. German and J. Moffet) along $12^{\circ} \mathrm{S}$ between Peru and Tahiti, a distance of $8500 \mathrm{~km}$ (Fig. 1). The sampling and analytical methods were largely the same as those employed during the U.S. GEOTRACES North Atlantic Transect in 2010-2011 (GA03; Charette et al., 2015) with further details described in Henderson et al., 2013. A brief description is thus reported below.

\subsection{Sample collection}

Radium isotopes were preconcentrated from seawater using $\mathrm{MnO}_{2}$ cartridges ("Mn-cartridges") deployed on modified McLane in situ pumps (ISPs). The ISPs were further modified after the GA03 cruise by adding a second $5^{\prime \prime}$ cartridge holder for determining actinium-227

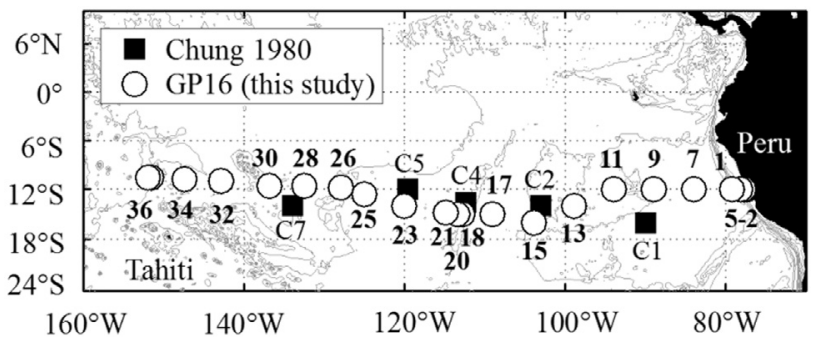

Fig. 1. Eastern Pacific Zonal Transect between Peru and Tahiti (US GEOTRACES GP16; Oct-Dec 2013; white circles). The position of stations from Chung (1980) are marked with solid squares.

$\left({ }^{227} \mathrm{Ac}\right)$ cartridge yields. A spring was also added to each cartridge holder in order to minimize seawater bypass through the cartridge, improving the Ra scavenging efficiency. Ten inch cellulose cartridges (3M Micro-Klean RB series, G80B2) were cut to 4", impregnated with $\mathrm{MnO}_{2}$, and deployed on each ISP for scavenging dissolved $(<1 \mu \mathrm{m}$ from the QMA and Supor prefilters) radium isotopes (Henderson et al., 2013). The ISPs were deployed at 23 stations with 16-24 depths sampled excluding shallower shelf stations. The ISP flow rates averaged $\sim 6 \mathrm{~L} \mathrm{~min}{ }^{-1}$ over $4 \mathrm{~h}$, which resulted in average filtration volumes of $1500 \pm 200 \mathrm{~L}$; lower volumes were usually associated with high particle loading that caused the prefilters to clog.

At these high ISP filtration rates, the Mn-cartridges do not scavenge $100 \%$ of the radium isotopes. Thus, at each sampling depth, separate samples $(21 \pm 2 \mathrm{~L})$ were collected from a $30 \mathrm{~L}$ Niskin bottle mounted above the ISP $(>1000 \mathrm{~m}$ ) or from a CTD rosette $(<1000 \mathrm{~m})$. These samples were gravity filtered through acrylic fiber impregnated with $\mathrm{MnO}_{2}$ ("Mn-fiber") at $<0.5 \mathrm{~L} \mathrm{~min}^{-1}$, which has been shown to quantitatively remove radium from seawater (Moore, 2008). The scavenging efficiencies of the Mn-cartridges were estimated by comparing the ${ }^{226} \mathrm{Ra}$ activity measured on the cartridge with the ${ }^{226} \mathrm{Ra}$ activity determined on the corresponding Niskin sample.

In addition to the ISP collection system, around $40 \mathrm{~g}$ of Mn-fiber was placed in a mesh bag and suspended in surface water $(<3 \mathrm{~m})$ at each station. The mesh bags were deployed between 8 and $55 \mathrm{~h}$ depending on the ship's time on station. The equivalent volume of seawater preconcentrated on the Mn-fiber ranged from 230 to $2500 \mathrm{~L}$, which was determined by comparing the ${ }^{226} \mathrm{Ra}$ activity measured on the Mn-fiber with the ${ }^{226}$ Ra activity determined from the surface water Niskin bottle.

Water column and surface water samples for the analysis of dissolved manganese (DMn), dissolved iron (DFe), and dissolved cobalt (DCo) were collected and processed following GEOTRACES trace metal clean protocols, as described by Sedwick et al. (2015), Resing et al. (2015) and Hawco et al. (2016), respectively.

\subsection{Laboratory analyses}

The Mn-fibers from the mesh bags were rinsed with radium free water, ashed, epoxy sealed, and analyzed using high purity, well-type germanium detectors (HPGe) at the University of South Carolina. Radium-228 was quantified from gamma lines at 338 and $911 \mathrm{keV}$ $\left({ }^{228} \mathrm{Ra}\right.$ daughter of $\left.{ }^{228} \mathrm{Ac}\right)$, and ${ }^{226} \mathrm{Ra}$ was measured through the $352 \mathrm{keV}{ }^{214} \mathrm{~Pb}$ peak. Mn-fiber ash standards of different heights were prepared from a NIST-certified ${ }^{226} \mathrm{Ra}$ solution (SRM\#4967A) and gravimetrically prepared ${ }^{232} \mathrm{Th}$ solution (activity confirmed through MC-ICP-MS); these were used to determine the counts per minute to disintegrations per minute conversion factors for the samples (a combination of gamma ray intensity and detector efficiency at different geometries) (Moore, 1984).

The $10 \mathrm{~g}$ Mn-fibers from the small-volume Niskin bottles were rinsed with MQ water, partially dried using compressed air, and placed into $125 \mathrm{~mL}$ PVC cartridge holders (Peterson et al., 2009). The samples 

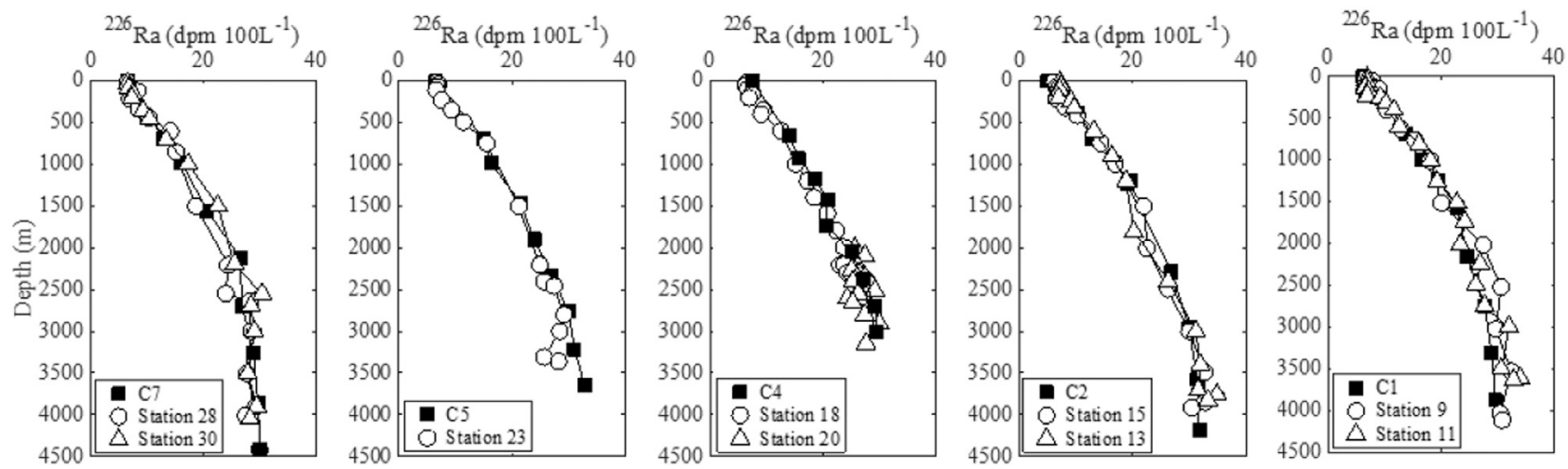

Fig. 2. Vertical profiles of ${ }^{226}$ Ra from US GEOTRACES GP16 (this study, open symbols) and from Chung, 1980 (closed symbols). Station locations are marked on Fig. 1.

were flushed with He for $5 \mathrm{~min}$ at $250 \mathrm{~mL} \mathrm{~min}^{-1}$, sealed and stored for a minimum of 12 days before analysis, which corresponds to at least $90 \%{ }^{222} \mathrm{Rn}$ ingrowth. The cartridge holders were then flushed for 15 min with He ( $\left.250 \mathrm{~mL} \mathrm{~min}^{-1}\right)$ through a cryo-loop cooled with liquid nitrogen, which serves to trap the ${ }^{222} \mathrm{Rn}$. The cryo-loop was then isolated and heated, and the ${ }^{222} \mathrm{Rn}$ was rapidly transferred from the cryoloop into an alpha scintillation cell (Lucas Cell) with a He flow rate of $450 \mathrm{~mL} \mathrm{~min}^{-1}$. The Lucas Cells were held for $3 \mathrm{~h}$ to allow the ${ }^{222} \mathrm{Rn}$ daughters to reach secular equilibrium (Key et al., 1979), then counted for $\sim 200 \mathrm{~min}$ on a radon counting system (Model AC/DC-DRC-MK 102). This method was calibrated using Mn-fibers loaded with $\sim 20 \mathrm{dpm}$ of ${ }^{226} \mathrm{Ra}$ (NIST-certified SRM\#4967A) and processed in the same way as the samples. These standards were processed at least once per month on each detector. Counting uncertainties typically range from 1 to $7 \%$ (1$\sigma)$, depending on the ${ }^{226} \mathrm{Ra}$ content on the Mn-fiber. These were propagated with the ${ }^{228} \mathrm{Ra} /{ }^{226} \mathrm{Ra}$ gamma analysis analytical uncertainty $(1-\sigma)$ in determining the uncertainties on the reported ${ }^{228} \mathrm{Ra}$ activities.

The Mn-cartridges and Mn-fibers were ashed at $820^{\circ} \mathrm{C}$ for $48 \mathrm{~h}$ and $24 \mathrm{~h}$, respectively (Charette et al., 2001, 2015). The ash was then transferred to polystyrene vials and sealed with epoxy to avoid ${ }^{222} \mathrm{Rn}$ loss. Gamma analyses were conducted in an underground laboratory in the French Alps (Laboratoire Souterrain de Modane, LSM) protected from cosmic radiation by the mountain with $1700 \mathrm{~m}$ of rock overhead (Reyss et al., 1995), which permitted the detection of the generally low ${ }^{228} \mathrm{Ra}$ activities. Samples were counted for 2-6 days on high purity, well-type germanium detectors. Six standards were used to calibrate the gamma detectors as described in Reyss et al. (1995). The ${ }^{228} \mathrm{Ra} /{ }^{226} \mathrm{Ra}$ activity ratios were determined only in samples collected on the first half of the transect (Stations 1-17; Fig. 1) and in the core of the hydrothermal plume (see Kipp et al. in this issue) using the ${ }^{228} \mathrm{Ra}$ activities estimated from the ${ }^{228} \mathrm{Ac}$ peaks $(338,911$, and $969 \mathrm{keV})$ and the ${ }^{226} \mathrm{Ra}$ activities estimated from the ${ }^{214} \mathrm{~Pb}$ peaks (295 and $352 \mathrm{keV}$ ) and ${ }^{214} \mathrm{Bi}$ peak (609 keV).

The scavenging efficiency of radium on the $\mathrm{MnO}_{2}$ cartridges was $66 \pm 16 \%(1-\sigma)$ over the entire GP16 cruise (improved relative to the U.S. Atlantic GEOTRACES cruises: $52 \pm 22 \%$; Charette et al., 2015). Given that the cartridge $\mathrm{MnO}_{2}$ impregnation method and the average ISP flow rate was the same for both cruises, the introduction of the spring in the cartridge holder is likely the main factor explaining the increased extraction efficiency. Further, the lower standard deviation for GP16 is an indication that reproducibility has also been improved. The ${ }^{228} \mathrm{Ra}$ and ${ }^{226} \mathrm{Ra}$ data are available on the BCO-DMO website (http://www.bco-dmo.org/dataset-deployment/650344).

Dissolved manganese was determined at sea as described by Resing et al. (2015). Dissolved iron was determined post-cruise at Old Dominion University by flow injection analysis with in-line preconcentration on resin-immobilized 8-hydroxyquinoline and colorimetric detection (Sedwick et al., 2015). Dissolved cobalt was determined post cruise following Hawco et al. (2016).

\section{Results and discussion}

\subsection{Distribution of Ra isotopes along the US GEOTRACES GP16 transect}

\subsubsection{Radium-226 distribution: relationship with hydrography}

The ${ }^{226} \mathrm{Ra}$ activities measured during GP16 were lowest within the

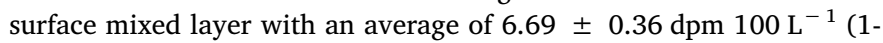
$\sigma)$. The highest ${ }^{226}$ Ra activity measured was $34.9 \pm 1.28 \mathrm{dpm} 100 \mathrm{~L}^{-1}$ (station 13, $3754 \mathrm{~m}$ depth). Chung (1980) reported ${ }^{226} \mathrm{Ra}$ profiles from 1969 and 1972 at stations located in close proximity to the GP16 transect (Fig. 2). In general, the ${ }^{226} \mathrm{Ra}$ activities measured for GP16 overlap with these historical measurements, and any minor offset is likely due to the slight differences in the station locations. Surface data reported by Chung (1980) from the Peru coastal ocean between $10^{\circ} \mathrm{S}$ and $20^{\circ} \mathrm{S}$ averaged $7.2 \pm 0.2 \mathrm{dpm} 100 \mathrm{~L}^{-1}$, which is consistent within the 1 sigma standard deviation of our data. The new data collected provide an important 40-year inter-calibration between the GEOSECS (1972) and GEOTRACES (SCOR Working Group, 2007) programs.

The "nutrient-like" profile of ${ }^{226} \mathrm{Ra}$ and the higher activities in the Pacific versus Atlantic deep waters activities led Broecker et al. (1967) to conclude that the ocean ${ }^{226} \mathrm{Ra}$ distribution is influenced by biogeochemical processes such as surface uptake and particle settling. It has been suggested that tests of siliceous phytoplankton play an important role in radium removal (Ku et al., 1970; Ku and Lin, 1976). As a result, the residence time of ${ }^{226} \mathrm{Ra}$ in the upper $1000 \mathrm{~m}$ has been estimated at 400 years by Moore and Dymond (1991), which is less than expected based solely on its half-life. Chung (1980) reported a linear relationship between ${ }^{226} \mathrm{Ra}$ and silicate in the upper $2000 \mathrm{~m}$ across the East Pacific Rise with a slope of $1.5 \times 10^{-3} \mathrm{dpm} \mathrm{Ra} \mu \mathrm{mol} \mathrm{Si}^{-1}$. This relationship was more variable below $2000 \mathrm{~m}$, which Chung (1980) and others hypothesized was due to the diffusion of radium from sediments produced by ${ }^{230}$ Th decay (Cochran, 1980). The general pattern of ${ }^{226} \mathrm{Ra}$ activities in the GP16 section is also similar to silicate, with homogeneous and low concentrations in the first $2000 \mathrm{~m}$, an increase of the concentration with depth and an asymmetry between the eastern part and the western part of the transect below $2000 \mathrm{~m}$ (Fig. 3). This asymmetry in silicate concentrations and ${ }^{226} \mathrm{Ra}$ activities is mainly the result of different deep water mass signatures for both ${ }^{226} \mathrm{Ra}$ and $\mathrm{Si}$.

The positions of the main water masses were identified by an Optimum Multiparameter Analysis (OMPA; Peters et al. in this issue; Fig. 3). Above $2000 \mathrm{~m}$, the ${ }^{226} \mathrm{Ra}$ distribution across the entire GP16 section was relatively homogeneous despite the presence of different surface and intermediate water masses (Fig. 3). Below $2000 \mathrm{~m}$, a high contribution of Pacific Deep Water (PDW) in the eastern part of the transect suggests a strong influence from North Pacific waters flowing south, whereas the presence of the Antarctic Bottom Water (AABW) and the Lower Circumpolar Deep Water (LCDW) indicates a northward flowing water mass in the western part of the transect (Peters et al. in this issue; Reid, 1997). The PDW is one of the oldest water masses, 


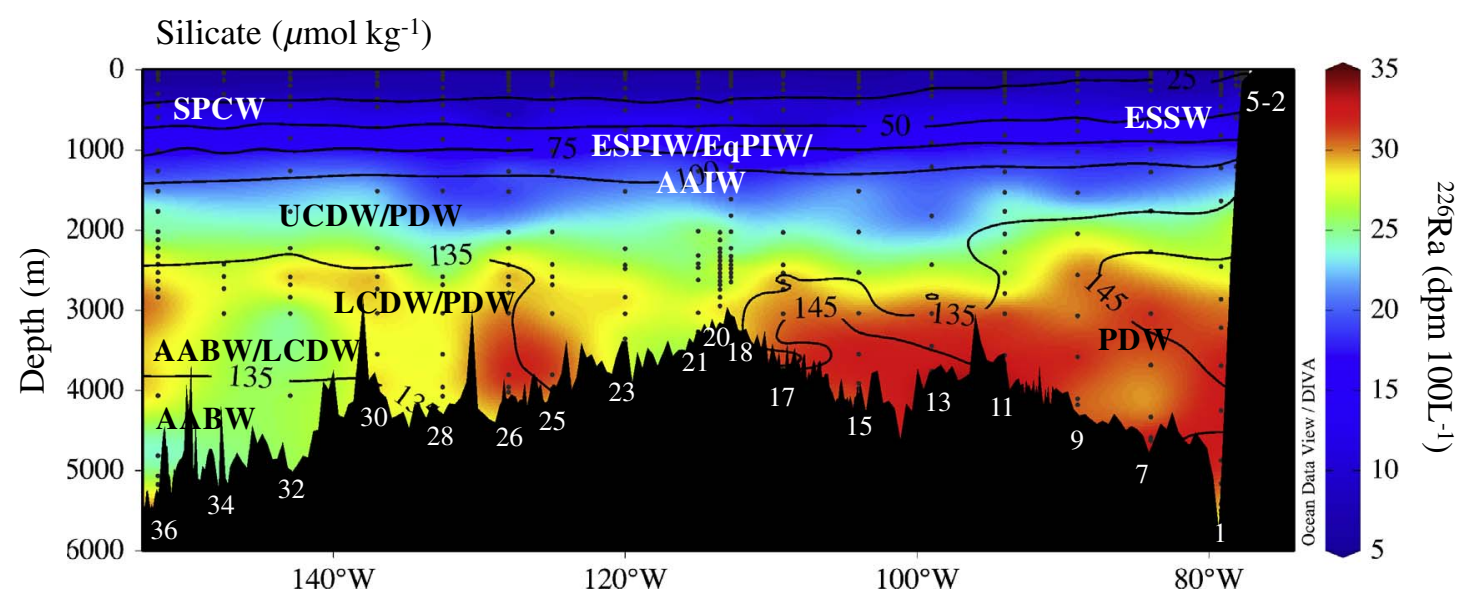

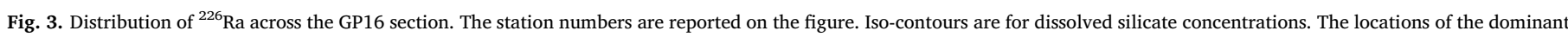

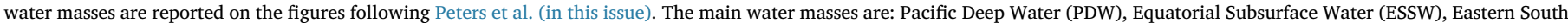

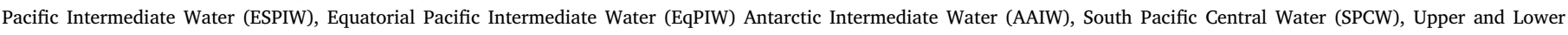
Circumpolar Deep Water (UCDW, LCDW), and Antarctic Bottom Water (AABW).

while AABW is relatively young (DeVries and Primeau, 2011; Khatiwala et al., 2012). As a consequence, ${ }^{226} \mathrm{Ra}$ activity increases from the deep Southern Ocean waters to the North Pacific waters (Broecker et al., 1967; Chung, 1974).

During GP16, only one sampling depth was located in the core of the AABW, characterized by low temperature $\left(<1{ }^{\circ} \mathrm{C}\right)$, high density $\left(\sigma_{\theta}>27.81 \mathrm{~kg} \mathrm{~m}^{-3}\right)$ and a ${ }^{226} \mathrm{Ra}$ activity of $23.1 \pm 0.7 \mathrm{dpm} 100 \mathrm{~L}^{-1}$ (station 36, $4733 \mathrm{~m}$; Fig. 4). This is consistent with previous measurements of ${ }^{226} \mathrm{Ra}$ activities in AABW, which range from 21 to $23 \mathrm{dpm} 100 \mathrm{~L}^{-1}$ (Chung and Craig, 1980; Ku and Lin, 1976). Pacific Deep Water has very distinct $\theta-S$ characteristics $\left(27.75 \mathrm{~kg} \mathrm{~m}^{-3}<\sigma_{\theta}<27.78 \mathrm{~kg} \mathrm{~m}^{-3}\right.$; Fig. 4). We observed PDW ${ }^{226} \mathrm{Ra}$ activities in the range of $28.7 \mathrm{dpm}$ $100 \mathrm{~L}^{-1}$ (station 17, $2700 \mathrm{~m}$ ) to $34.9 \mathrm{dpm} 100 \mathrm{~L}^{-1}$ (station $13,3754 \mathrm{~m}$ ). These are in agreement with the large range of values reported for PDW (28-47 dpm $100 \mathrm{~L}^{-1}$; Chan et al., 1976; Chung and Craig, 1973). On the western half of the GP16 transect, PDW and AABW are mixed with Lower Circumpolar Deep Water (LCDW) (Fig. 3), which is consistent with the reported ${ }^{226} \mathrm{Ra}$ activities given that the ${ }^{226} \mathrm{Ra}$ in Circumpolar Deep Water ranges from 16 to $20 \mathrm{dpm} 100 \mathrm{~L}^{-1}$ (Hanfland, 2002; Ku and Lin, 1976;

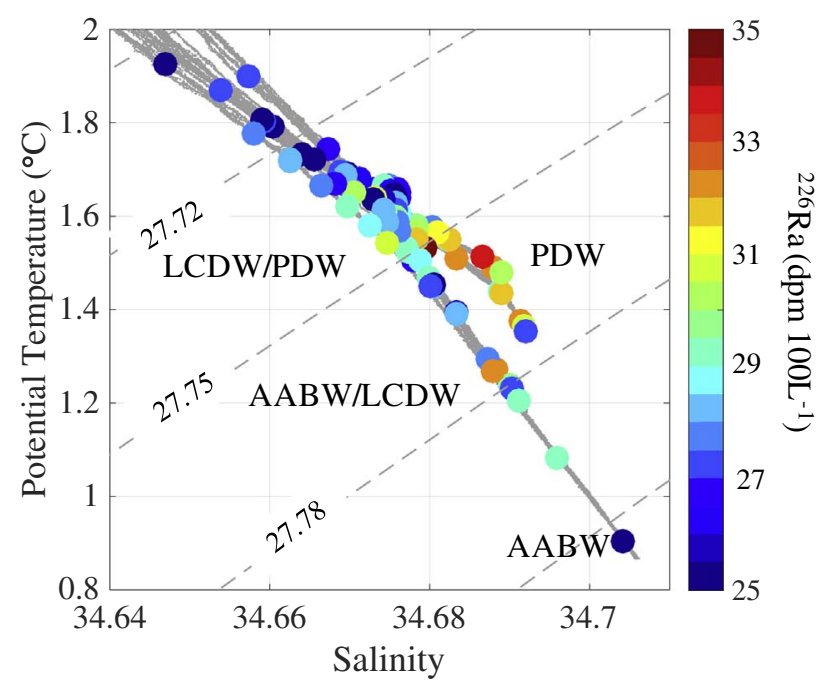

Fig. 4. Potential temperature $(\theta)$ - Salinity diagram for depths $>2000 \mathrm{~m}$ across the GP 16 section (gray lines). The dashed lines represent the isopycnals $\left(\mathrm{kg} \mathrm{m}^{-3}\right)$ while the ${ }^{226} \mathrm{Ra}$ activities are shown by the color of the symbols. The reported water masses are: Pacific Deep Water (PDW), Lower Circumpolar Deep Water (LCDW), and Antarctic Bottom Water (AABW). van Beek et al., 2008). The relatively high ${ }^{226} \mathrm{Ra}$ activities in the AABW/ LCDW, around $27.78 \mathrm{~kg} \mathrm{~m}^{-3}$, are associated with samples collected particularly close to the seafloor at station 25 and $26(<20 \mathrm{~m}$ from the seafloor), and are likely due to diffusive input from deep sediments (Hammond et al., 1990; Huh and Ku, 1998).

\subsubsection{Radium-228 distribution}

Unlike ${ }^{226} \mathrm{Ra}$, oceanic ${ }^{228} \mathrm{Ra}$ distributions are not strictly related to major water masses due to the shorter half-life (5.75 years). Radium228 activities in the Pacific Ocean are generally one order of magnitude lower than in the Atlantic Ocean, a result of dilution and decay in the significantly larger Pacific basin relative to its continental margin area (Charette et al., 2015; Knauss et al., 1978; Li et al., 1980; Moore, 1969a, 1969b; van Beek et al., 2007). Larger continental ${ }^{228} \mathrm{Ra}$ inputs in the Atlantic Ocean could also play a role in the difference (Kwon et al., 2014). For the GP16 section, ${ }^{228} \mathrm{Ra}$ ranged from below detection limit to $0.64 \pm 0.08 \mathrm{dpm} 100 \mathrm{~L}^{-1}$, with the highest activity found on the Peruvian shelf (station 3, $13 \mathrm{~m}$ ). Over the shelf, ${ }^{228} \mathrm{Ra}$ activities increased with distance from shore, which is atypical given the expected strong source of ${ }^{228} \mathrm{Ra}$ from terrestrial runoff and margin sediments. In the off-shelf surface water, ${ }^{228}$ Ra peaked at stations 7 and 9, after which activities decreased with the increasing distance from the coastline (Fig. 5).

The ${ }^{228}$ Ra activities measured during GP16 fall within the range of the few Pacific Ocean studies that have reported on this isotope (Huh and Ku, 1998; Kaufman et al., 1973; Knauss et al., 1978; Moore, 1969a, 1969b; Yamada and Nozaki, 1986). More precisely, station 7 (84 $\left.{ }^{\circ} \mathrm{W}\right)$, station $9\left(89^{\circ} \mathrm{W}\right)$, station $13\left(99^{\circ} \mathrm{W}\right)$, and station $25\left(125^{\circ} \mathrm{W}\right)$ display very similar surface ${ }^{228} \mathrm{Ra}$ activities as those from the $1960-1970$ s (Kaufman et al., 1973; Knauss et al., 1978; Fig. 5). We note, that in these previous studies, fixed ${ }^{226} \mathrm{Ra}$ values of $6.5 \mathrm{dpm} 100 \mathrm{~L}^{-1}$ and $8.5 \mathrm{dpm} 100 \mathrm{~L}^{-1}$ were assumed in order to estimate the ${ }^{228} \mathrm{Ra}$ activities, based on measured ${ }^{228} \mathrm{Ra} /{ }^{226} \mathrm{Ra}$ activity ratios in Knauss et al. (1978) and Kaufman et al. (1973), respectively. The average ${ }^{226} \mathrm{Ra}$ activity in the mixed layer depth during GP16 was $6.69 \pm 0.36 \mathrm{dpm}$ $100 \mathrm{~L}^{-1}$.

The difference in ${ }^{228} \mathrm{Ra}$ activities between GP16 and historical values over the shelf $\left(0.2-1.9 \mathrm{dpm} 100 \mathrm{~L}^{-1}\right.$, collected in March 1973; Knauss et al., 1978) are probably due to a combination of seasonal and interannual variability in ${ }^{228} \mathrm{Ra}$ inputs, along shore currents, and/or upwelling. The ${ }^{228} \mathrm{Ra}$ activities measured during GP16 are in the lower range of the historical data. Seasonal variability in ${ }^{228} \mathrm{Ra}$ has been observed in the U.S. North Atlantic coast with lower ${ }^{228} \mathrm{Ra}$ excess activities relative to offshore waters in winter as compared to summer (Kelly and 

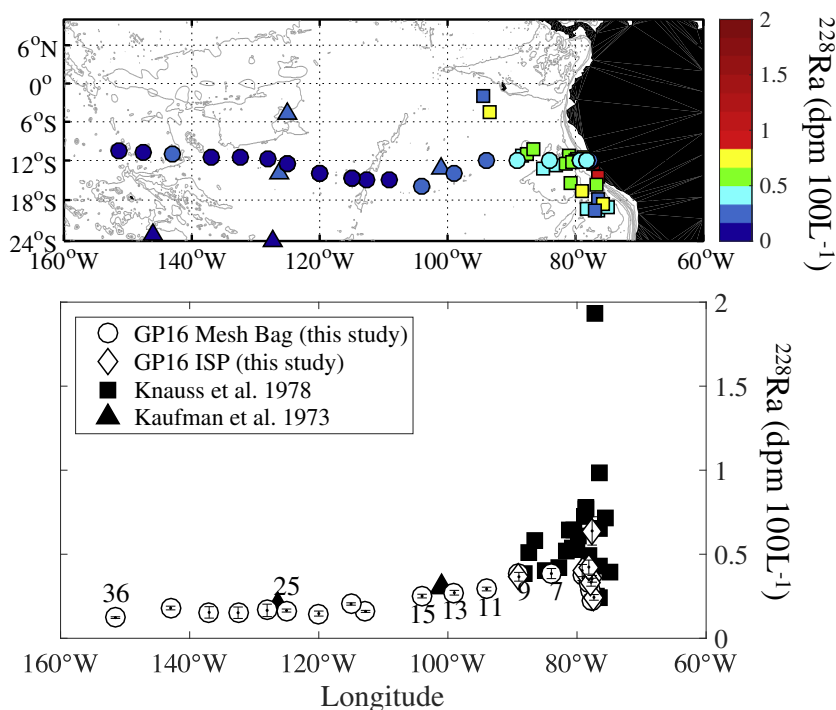

Fig. 5. Map of the surface ${ }^{228} \mathrm{Ra}$ activities off Peru (a). The activities of the stations located within the range of $6-18^{\circ} \mathrm{S}$ are reported on a graph versus longitude (b). The circles represent the ${ }^{228} \mathrm{Ra}$ activities from the mesh bag data (this study), diamonds represent the ${ }^{228} \mathrm{Ra}$ activities from the shallow in situ pumps $(<20 \mathrm{~m}$; this study), squares are data from Knauss et al. (1978), and triangles are from Kaufman et al. (1973).

Moran, 2002; Moore, 2007; Moore and Shaw, 2008). Seasonality in ${ }^{228} \mathrm{Ra}$ has been attributed to changes in SGD inputs (e.g. Moore, 1999), sea level, and wave/tide forcing (e.g. Gonneea et al., 2013; Robinson et al., 2006). However, while SGD is the dominant source of ${ }^{228} \mathrm{Ra}$ in the North Atlantic, its contribution to the ${ }^{228} \mathrm{Ra}$ coastal input in the South Pacific is thought to be similar to river and sediment inputs (Kwon et al., 2014). Temporal variations in upwelling over the shelf, which is low in ${ }^{228} \mathrm{Ra}$ and thus dilutes the coastal ${ }^{228} \mathrm{Ra}$ signal in surface waters, may also have an impact on surface ${ }^{228} \mathrm{Ra}$ activities (Huh and Ku, 1998; Knauss et al., 1978); indeed, the intensity of the upwelling off Peru due to fluctuations of El Niño Southern Oscillation (ENSO) has been shown to vary over seasonal to interannual timescales (Pennington et al., 2006; Scheidegger and Krissek, 1983). The ENSO conditions were neutral during the GP16 cruise in Oct-Nov 2013 (IRN ENSO Forecast) while they were at the end of an intense El Niño cycle in March 1973 (Ramage, 1975). The stronger upwelling in 2013 relative to 1973 could thus explain the lower ${ }^{228} \mathrm{Ra}$ activities measured at the surface during GP16. The passage of eddies (Czeschel et al., 2015; Pegliasco et al., 2015) may also influence the relative proportions of offshore, upwelled, and coastal waters at a particular sampling site.

Consistent with the surface distribution, elevated ${ }^{228} \mathrm{Ra}$ activities down to $200 \mathrm{~m}$ were observed from the shelf to $104^{\circ} \mathrm{W}$ (station 15 , $\sim 3000 \mathrm{~km}$ from the coast), decreasing thereafter but remaining well above the detection limit to $150^{\circ} \mathrm{W}$, suggesting relatively recent contact (years to decades) of surface water with the continental margin (Fig. 6). The ${ }^{228} \mathrm{Ra}$ decrease at $104^{\circ} \mathrm{W}$ is consistent with a physical (transition to warmer and saltier water; Peters et al. in this issue) and biological (change in phytoplankton and zooplankton community structure; Ohnemus et al., 2016) frontal region. The highest ${ }^{228} \mathrm{Ra}$ activities were above the $26 \mathrm{~kg} \mathrm{~m}^{-3}$ isopycnal, which ranged from $20 \mathrm{~m}$ (station 3 , shelf) to $280 \mathrm{~m}$ (station 15) due to the upwelling-driven lifting of the isopycnal along the Peru margin (Lentz and Chapman, 2004).

The eastern tropical Pacific is characterized by a shallow and strong permanent pycnocline that limits ventilation of subsurface waters resulting in very low subsurface oxygen concentrations (Fiedler and Talley, 2006). As a consequence, penetration of the ${ }^{228} \mathrm{Ra}$ signal to intermediate waters is less than typically observed in other ocean basins (e.g. Charette et al., 2015). Seasonal variation in the pycnocline depth is quite small ( $< \pm 10 \mathrm{~m}$; Fiedler and Talley, 2006). However, because of the shallowness of the pycnocline, even such small variations in depth can impact ${ }^{228} \mathrm{Ra}$ activities over the shelf.

The ${ }^{228} \mathrm{Ra}$ activities decreased from the surface with increasing depth and were generally $<0.1 \mathrm{dpm} 100 \mathrm{~L}^{-1}$ in the mid water column with the exception of stations close to the Peruvian margin, where significant ${ }^{228} \mathrm{Ra}$ activities were observed between $\sim 1000-2500 \mathrm{~m}$ up to $600 \mathrm{~km}$ from the slope (station 1; Fig. 7). Since the ${ }^{228} \mathrm{Ra}$ activities decreased to near background values at $200 \mathrm{~m}$, this mid water ${ }^{228} \mathrm{Ra}$ must be derived from slope sediment input and horizontal transport along isopycnal surfaces (Sarmiento et al., 1982).

A relatively high ${ }^{228} \mathrm{Ra}$ activity $\left(0.127 \pm 0.032 \mathrm{dpm} 100 \mathrm{~L}^{-1}\right)$ was measured at station 9, $1000 \mathrm{~m}$, which can only be explained by recent contact with sediments (Fig. 6). Unfortunately, the depth range over which this signal extends is unknown because the next sample analyzed was at $2500 \mathrm{~m}$ and displayed a low activity. Bowman et al. (2016) found a similar anomaly for total mercury concentrations (HgT) at this station that extended down to $2000 \mathrm{~m}$. Hawco et al., 2016 also reported high concentrations of dissolved and labile Co at station 9, likely due to a shelf source; however, this Co anomaly is located at shallower depths (100-200 m). The Peru upwelling system is well known for generating numerous eddies that are typically formed near the coast and move westward with temperature and salinity anomalies down to $800 \mathrm{~m}$ (Pegliasco et al., 2015); one of these may have transported shelf water and have generated the Co anomaly. Highly energetic mesoscale eddies that can extend vertically down to $2000 \mathrm{~m}$ have also been identified in the eastern South Pacific (Chaigneau and Pizarro, 2005), which could potentially explain this deep ${ }^{228} \mathrm{Ra}$ anomaly at station 9 . However, no specific vertical features in temperature, salinity or nutrients have been identified at this station to confirm the presence of an eddy.

The ${ }^{228}$ Ra activities increased again close to the bottom, likely due to diffusive input from seafloor sediments (Hammond et al., 1990; Huh and Ku, 1998). Near-bottom ${ }^{228}$ Ra activities were especially high in the very narrow $6000 \mathrm{~m}$ deep Peru-Chile Trench (station 1) and at stations 7 and 9 (Fig. 6). In the case of station 1, these high activities may be a result of benthic input from both slopes of the trench. Sediment remobilization as indicated by the high concentration of lithogenic particles at the bottom of stations 7 and 9 and subsequent desorption could also potentially explain the high ${ }^{228} \mathrm{Ra}$ activities at this location (Lam et al. in this issue).

\subsection{Shelf and slope ${ }^{228} \mathrm{Ra}$ fluxes}

Kwon et al. (2014) developed an inverse model based on a global database of water column ${ }^{228} \mathrm{Ra}$ measurements to derive the shelf ${ }^{228} \mathrm{Ra}$ flux necessary to balance the upper ocean ${ }^{228} \mathrm{Ra}$ inventory. Their $2^{\circ} \times 2^{\circ}$-resolution model results suggested that the sources of ${ }^{228} \mathrm{Ra}$ to the South Pacific Ocean are relatively equally distributed between SGD, rivers, and sediments with an average combined ${ }^{228} \mathrm{Ra}$ flux from the

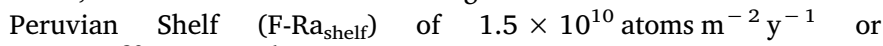
$5.9 \times 10^{20}$ atoms $y^{-1}$ for a model grid point (Kwon et al., 2014).

In this model, margin inputs of ${ }^{228} \mathrm{Ra}$ to the open ocean below $1000 \mathrm{~m}$ were not considered. However, we observed significant ${ }^{228} \mathrm{Ra}$ activities between $\sim 1000-2500 \mathrm{~m}$ in close proximity to the Peruvian slope, and as noted earlier, diffusion from sediments deposited on the continental slope is likely the major source of this ${ }^{228} \mathrm{Ra}$ (Fig. 6). Deep sea ${ }^{228} \mathrm{Ra}$ distributions are generally dominated by mixing along isopycnal surfaces (Sarmiento and Rooth, 1980; Sarmiento et al., 1982), which were essentially horizontal between $1000 \mathrm{~m}$ and $3000 \mathrm{~m}$ suggesting that there was little to no influence of upwelling at these depths. Changes in ${ }^{228} \mathrm{Ra}$ distribution due to vertical diffusion $\left(\mathrm{K}_{\mathrm{z}}\right)$ are also likely to be minor. Whalen et al. (2012) estimated a $K_{z}$ of $10^{-6} \mathrm{~m}^{2} \mathrm{~s}^{-1}$ for $1000-2000 \mathrm{~m}$ in the eastern equatorial Pacific. Using the approximation that the mean transport distance is $2 \sqrt{\mathrm{K}_{\mathrm{z}}{ }^{\times} \mathrm{t}}$ (solution of a 1D equation for diffusion of a point source) indicates a migration of $30 \mathrm{~m}$ over the mean ${ }^{228} \mathrm{Ra}$ life $(\mathrm{t}=1 / \lambda$ where $\lambda$ is the ${ }^{228}$ Ra decay constant). While higher diffusivities may apply close to the seabed, once the input migrates away from the slope, there should be minimal dilution due to vertical transport. 


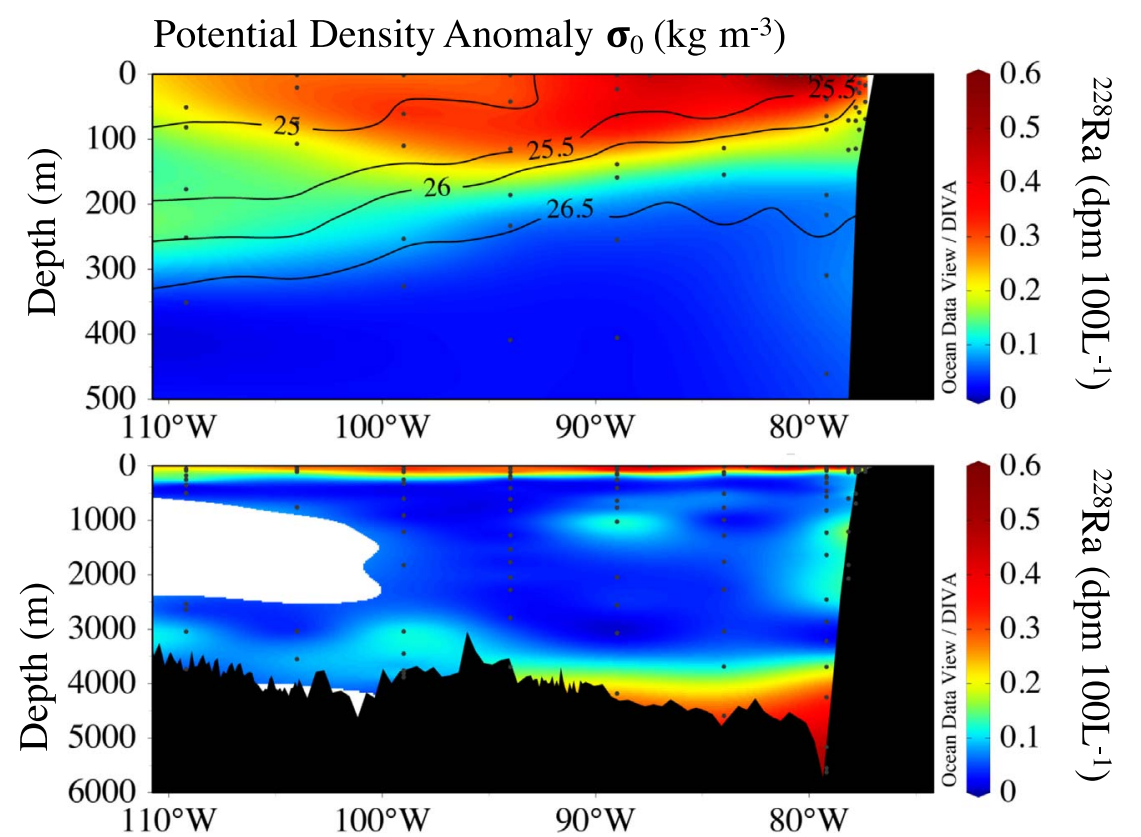

Fig. 6. Distribution of ${ }^{228} \mathrm{Ra}$ activities across the GP16 section in the first $500 \mathrm{~m}$ of the water column (top) and over the entire water column (bottom). Isocontours represent the potential density anomaly.

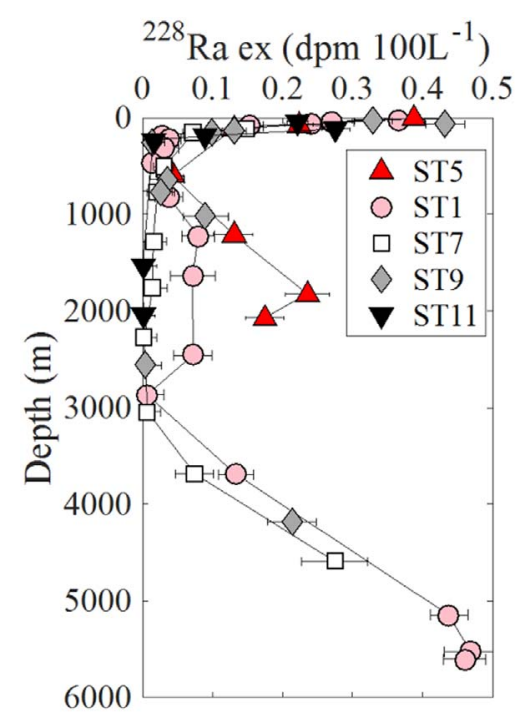

Fig. 7. Vertical profiles of excess ${ }^{228} \mathrm{Ra}\left({ }^{228} \mathrm{Ra}_{\mathrm{ex}}\right)$ at stations 5 to 11.

Given our assumptions that horizontal advection and vertical mixing are negligible, and that radium behaves conservatively, the only sinks would be horizontal diffusion and radioactive decay. The distribution of ${ }^{228} \mathrm{Ra}$ with distance from the slope can then be described as:

$\frac{\mathrm{dC}}{\mathrm{dt}}=\mathrm{K}_{\mathrm{h}} \frac{\partial^{2} \mathrm{C}}{\partial \mathrm{x}^{2}}-\lambda \mathrm{C}$

where $C$ is the excess ${ }^{228} \mathrm{Ra}$ concentration (atoms $\mathrm{m}^{-3}$ ), $\mathrm{t}$ is time, $\mathrm{K}_{\mathrm{h}}$ is the horizontal eddy diffusion coefficient $\left(\mathrm{m}^{2} \mathrm{~s}^{-1}\right)$, and $\mathrm{x}$ is the zonal distance from the slope (Moore, 2000). While shelf inputs of ${ }^{228}$ Ra may display seasonal variability due to variations in upwelling intensity or river inputs, the source of radium from the slope is probably relatively constant. This allows us to assume steady-state for Eq. (1) below $1 \mathrm{~km}$, which is less likely at the surface considering the timescale over which ${ }^{228} \mathrm{Ra}$ integrates (Moore, 2015). Applying a boundary condition where $\mathrm{C}$ decreases to zero as $\mathrm{x}$ approaches infinity, Eq. (1) can be rearranged as follows:
$\mathrm{C}(\mathrm{x})=\mathrm{C}_{0} \mathrm{e}^{-\mathrm{xa}}$, where $\mathrm{a}=\sqrt{\lambda / \mathrm{K}_{\mathrm{h}}}$

Given the boundary condition noted above, ${ }^{228}$ Ra must be corrected for the mid water column background concentration, which we determined from the average of the ${ }^{228} \mathrm{Ra}$ activities between $1000 \mathrm{~m}$ and $3000 \mathrm{~m}$ across $94^{\circ} \mathrm{W}$ to $110^{\circ} \mathrm{W}$ (stations 11-17; $\mathrm{n}=13$; $0.048 \pm 0.009 \mathrm{dpm} 100 \mathrm{~L}^{-1}$ or $2.1 \pm 0.39 \times 10^{6}$ atoms $\mathrm{m}^{-3}$ ). This background value is not an analytical blank; rather it is likely to reflect the average mid-water ${ }^{228} \mathrm{Ra}$ activity due to diapycnal mixing from the surface and deep ocean maxima or possibly from horizontal transport from distant, isolated topographic highs (not from in situ production from its parent ${ }^{232} \mathrm{Th}$, which contributes $<1 \%$ of the ${ }^{228} \mathrm{Ra}$ value used here; $\sim 2.4 \times 10^{-4} \mathrm{dpm} 100 \mathrm{~L}^{-1}$ Lopez et al., 2015). The ${ }^{228} \mathrm{Ra}$ activities thus corrected for background activities are denoted as excess ${ }^{228} \mathrm{Ra}\left({ }^{228} \mathrm{Ra}_{\mathrm{ex}}\right)$.

Assuming that the exponential decrease of ${ }^{228} \mathrm{Ra}_{\mathrm{ex}}$ concentrations between $1000 \mathrm{~m}$ and $2500 \mathrm{~m}$ with increasing distance from the margin is dominated by horizontal eddy diffusion, we use Eq. (2) to derive a mean $\mathrm{K}_{\mathrm{h}}$ of $46 \mathrm{~m}^{2} \mathrm{~s}^{-1}$ for this depth range (Fig. 8). Estimates of $\mathrm{K}_{\mathrm{h}}$ at specific depths $1200 \mathrm{~m}, 1800 \mathrm{~m}$, and $2400 \mathrm{~m}$ were $94 \mathrm{~m}^{2} \mathrm{~s}^{-1}$, $24 \mathrm{~m}^{2} \mathrm{~s}^{-1}$, and $49 \mathrm{~m}^{2} \mathrm{~s}^{-1}$, respectively. The similar magnitude of $\mathrm{K}_{\mathrm{h}}$ estimates suggest a low spatial variability in mixing over the studied depth range. The $\mathrm{K}_{\mathrm{h}}$ calculated is two orders of magnitude lower than the ${ }^{228}$ Ra-based $K_{h}$ of Sarmiento et al. (1982) estimated for the abyssal

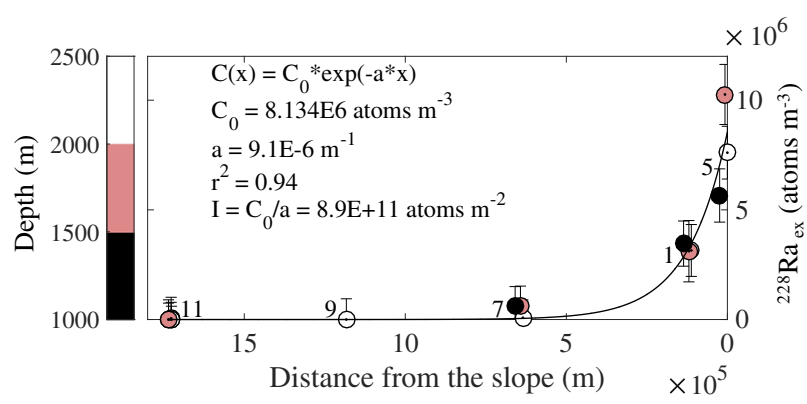

Fig. 8. Distribution of ${ }^{228} \mathrm{Ra}_{\mathrm{ex}}$ concentrations between $1000 \mathrm{~m}$ and $2500 \mathrm{~m}$ as a function of distance from the slope. The depth range of the samples is indicated by the color of the symbols. The station numbers are reported next to the data symbols. 
North Atlantic Basin, although mixing in their study area should be more vigorous than along the Peru slope, with a significant impact on horizontal eddy strength. Furthermore, the basin-wide scale of their study is significantly larger than our margin region, which fits the known trend of increasing $\mathrm{K}_{\mathrm{h}}$ with increasing mixing length scale (Okubo, 1971). A recent ocean-wide compilation of $K_{h}$ at scales of $300 \mathrm{~km}$ (Cole et al., 2015) based on salinity variations on isopycnals observed with Argo floats, reports regional values at $12^{\circ} \mathrm{S}$ in the $1-2 \mathrm{~km}$ depth range that are less than an order of magnitude greater than those calculated here. Regardless, the simultaneous observation of the TEI concentration field and the tracer-derived diffusivity should offer a more robust interpretation of the TEI fluxes to be calculated in subsequent sections.

The Peru-Chile upwelling system is well-known for generating numerous eddies. However, the mesoscale eddies generated by the eastern boundary upwelling system in the Peru-Chile area are limited to the first $600 \mathrm{~m}$ of the water column (e.g. Pegliasco et al., 2015). The influence of mesoscale surface and subsurface eddies is thus very limited in the depth range of $1000-2500 \mathrm{~m}$. Some horizontal jets have been identified at $1000 \mathrm{~m}$ and $1500 \mathrm{~m}$ in the Tropical Pacific Ocean but they are likely stronger on the western side of the basin and tend to disappear as they approach the South American coast (Cravatte et al., 2012). We think an advection-dominated system is less likely than a diffusion-dominated system due to the linear gradient in dissolved Mn, which will be discussed later. In shallower waters, between 300 and $1000 \mathrm{~m}$, it may be that the offshore diffusive transport of ${ }^{228} \mathrm{Ra}$ is suppressed by an onshore component of advection, explaining the absence of an excess in these depths. However, this is speculative; the required velocities would be difficult to detect by direct measurement or geostrophy. Finally, and perhaps most importantly, the mixing rate calculated above is an "effective" horizontal eddy diffusion coefficient, one that accounts for both advection and diffusion as the distribution of radium with distance from the continental slope is actually affected by both processes.

$\mathrm{A}^{228} \mathrm{Ra}$ flux from the slope $\left(\mathrm{F}-\mathrm{Ra}_{\text {slope }}\right)$ sediments can be determined as:

$\mathrm{F}^{-\mathrm{Ra}_{\text {slope }}}=\mathrm{I} \lambda \sin \theta$

where $\mathrm{I}$ is the inventory of ${ }^{228} \mathrm{Ra}_{\mathrm{ex}}$ over the depth range of interest and $\theta$ is the inclination of the slope $\left(2.06^{\circ}\right)$. The inventory of ${ }^{228} \mathrm{Ra}$ between $1000 \mathrm{~m}$ and $2500 \mathrm{~m}$ is equal to the area under the curve in a plot of ${ }^{228} \mathrm{Ra}$ concentration against distance from the slope (Fig. 8); in practice, it is estimated by taking the integral of Eq. (2), where $C_{0} / a=I$ $\left(8.9 \times 10^{11}\right.$ atoms $\left.\mathrm{m}^{-2}\right)$. Substituting I into Eq. (3) gives a F-Ra slope $_{\text {of }}$ 120 atoms $\mathrm{m}^{-2} \mathrm{~s}^{-1}\left(3.8 \times 10^{9}\right.$ atoms $\left.\mathrm{m}^{-2} \mathrm{y}^{-1}\right)$, which is comparable to ${ }^{228} \mathrm{Ra}$ slope fluxes estimated by Hammond et al. (1990) for the San Nicolas (335 atoms $\mathrm{m}^{-2} \mathrm{~s}^{-1}$, oxic conditions) and San Pedro (166 atoms $\mathrm{m}^{-2} \mathrm{~s}^{-1}$, anoxic conditions) Basins located offshore from Southern California (USA).

The same approach could be used to estimate the $\mathrm{F}-\mathrm{Ra}_{\text {shelf }}$ since the offshore ${ }^{228} \mathrm{Ra}$ inventory must be supplied by coastal inputs and transport via diffusion and advection. The weighted ${ }^{228} \mathrm{Ra}$ activities were estimated from stations 5 through 17 for all samples above the $26 \mathrm{~kg} \mathrm{~m}^{-3}$ isopycnal and were plotted as a function of the distance from the shelf (Fig. 9). The ${ }^{228} \mathrm{Ra}$ inventory is estimated at $6.8 \times 10^{12}$ atoms $\mathrm{m}^{-2}$. Considering an inclination of the shelf of $0.38^{\circ}$ and using the Eq. (3), the $\mathrm{F}_{-} \mathrm{Ra}_{\text {shelf }}$ is $0.6 \times 10^{10}$ atoms $\mathrm{m}^{-2} \mathrm{y}^{-1}$, within a factor of three of the Kwon et al. (2014) estimate. While there is some concern about the validity of the assumptions used in deriving the 1D diffusion-decay model for the upper ocean, the relatively good agreement with the global-scale model of Kwon et al. (2014) suggests these assumptions may be reasonable. Nonetheless, the $\mathrm{F}-\mathrm{Ra}_{\text {shelf }}$ from Kwon et al. (2014) inverse model will be considered in the rest of the manuscript since this approach may incorporate ${ }^{228} \mathrm{Ra}$ sources from beyond the Peruvian shelf while the global model does not, and it takes into account the global ocean circulation and seasonal variability in shelf inputs.

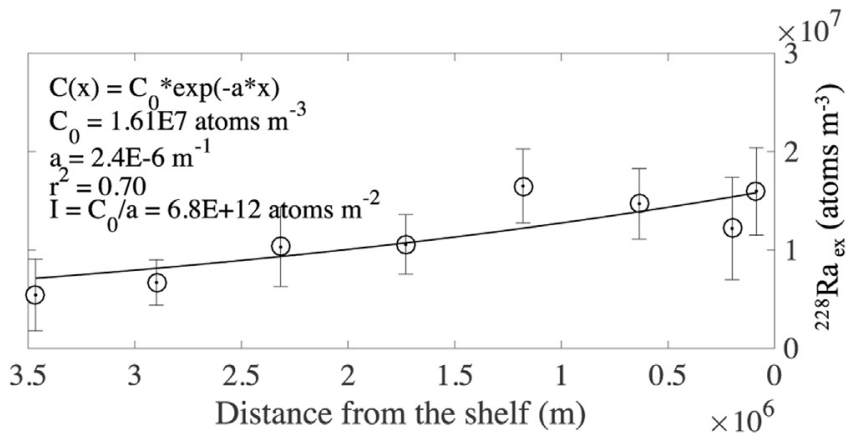

Fig. 9. Distribution of weighted average of ${ }^{228} \mathrm{Ra}$ (stations $1,5-17$ ) between the surface and the $26 \mathrm{~kg} \mathrm{~m}^{-3}$ isopycnal as a function of the distance from the shelf.

The per unit area F-Raslope is about $25 \%$ of the shelf flux; the lower slope rate may reflect differences in the composition of sediments and/ or the processes transporting radium from pore fluids to overlying waters. In terms of total ${ }^{228} \mathrm{Ra}$ inputs, the ocean flux from the margin is dominated by the shelf input, in part because of the higher flux per unit area, but also because the shelf area is much greater than the area of the upper slope. This difference alone would cause the rapid decrease in ${ }^{228} \mathrm{Ra}$ with depth seen in the profiles below $100 \mathrm{~m}$. The subsequent rise in ${ }^{228} \mathrm{Ra}$ activities below $500 \mathrm{~m}$ is less easily explained, though we argue that this pattern may reflect a combination of three factors. First, the upwardly tilting isopycnals above this horizon suggest that a component of onshore flow must be present, limiting offshore transport of Ra. Second, at each station, horizons below $500 \mathrm{~m}$ were closer to the margin than the horizons sampled above. Third, the compilation of Cole et al. (2015) suggests that horizontal eddy diffusivity should decrease with depth, perhaps causing the modest benthic input in the $100-500 \mathrm{~m}$ depth range to be so diluted by rapid transport that the concentration approaches detection limits.

\subsection{TEI distributions relative to ${ }^{228} \mathrm{Ra}$ in the upper water column}

Ocean dissolved TEI concentrations are controlled by a balance between their sources (e.g. sediments, hydrothermal vents, rivers, SGD, aeolian depositions) and sinks (e.g. biological uptake, precipitation, scavenging; Bruland and Lohan, 2003). The TEI distribution depends on the rates of each process including mixing and transport (Noble et al., 2012). Among the TEIs, dissolved manganese (DMn), cobalt (DCo), and iron (DFe) are important micronutrients that are redox active and present in seawater at extremely low concentrations (nM-pM) due to scavenging and low solubility (McManus et al., 2012; Saito et al., 2004). Each is affected by internal biogeochemical cycling processes occurring at different rates. For instance, DFe is rapidly scavenged from the upper ocean (Landing and Bruland, 1987), while scavenging removal of DCo is relatively slow (Noble et al., 2012). In addition, biological processes play an essential role in the geochemical cycling of Co (Sunda and Huntsman, 1995b), Fe (Sunda and Huntsman, 1995a), and Mn (Sunda et al., 1983), with dissolved Fe exhibiting the most nutrient like behavior (Johnson et al., 1997). Manganese, Co, and Fe are cofactors in enzymes and structural elements in proteins. As a consequence, their extremely low concentrations in seawater may actively control the rate of the photosynthesis (Morel and Price, 2003). Due to biological uptake, DFe and DCo are depleted at the surface. In contrast, DMn concentrations are maximum at the surface because of the photochemical reduction of $\mathrm{Mn}$ oxides to soluble Mn (Sunda and Huntsman, 1988).

The ${ }^{228} \mathrm{Ra}$ plume in the upper $200 \mathrm{~m}$ extends from the Peru margin to the open ocean (Fig. 6) and provides evidence of recent contact of shelf waters with sediments. Most of these upper ocean waters contained high concentrations of dissolved oxygen; thus, this shelf plume is situated above the Peru OMZ (Fig. 10a). Similarly, the highest DMn 

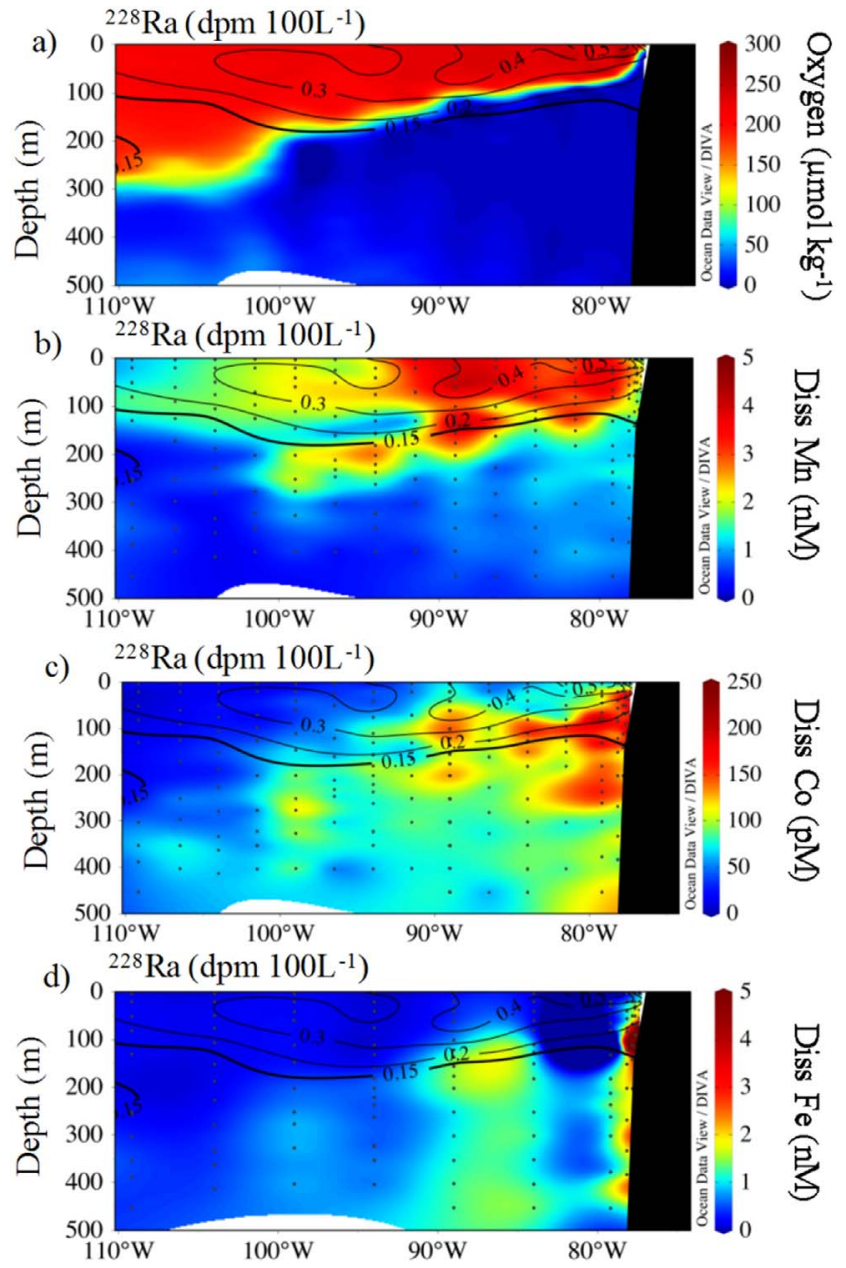

Fig. 10. Distribution of oxygen (a), dissolved Mn (b), dissolved Co (c), and dissolved Fe (d) in the upper water column ( $>500 \mathrm{~m}$ ). The isocontours represent the distribution of ${ }^{228} \mathrm{Ra}$ activities.

concentrations were measured within the shelf plume, suggesting a common source with ${ }^{228} \mathrm{Ra}$. Note that a secondary DMn maximum was observed below the shelf plume along the oxycline near $95^{\circ} \mathrm{W}$ (Fig. 10b), which likely results from remineralization of organic matter rather than reduction of manganese oxides (Vedamati et al., 2015).

Dissolved Co and DFe displayed very different patterns compared with DMn. Whereas relatively high DCo concentrations were measured in the shelf plume, a broad DCo maximum was found in subsurface waters (Fig. 10c) suggesting an intense water column remineralization source (Hawco et al., 2016). In general, DFe concentrations were low within the shelf plume, though high DFe concentrations were found in the near bottom samples (Fig. 10d). A rapid decrease of DFe concentrations across the Peruvian shelf was previously reported by Bruland et al. (2005). They showed that shelf-derived DFe was not transported beyond $81^{\circ} \mathrm{W}(\sim 300 \mathrm{~km}$ from the coast), which is in agreement with the highly particle-reactive behavior of Fe (Landing and Bruland, 1987; Boyd and Ellwood, 2010). Vedamati et al. (2014) also reported an abrupt decrease in DFe and Fe(II) along three different transects across the Peruvian shelf break, and suggested oxidative scavenging was the main removal process, which is consistent with the more rapid westward decrease in DFe in the oxygenated surface waters along GP16, compared with DCo and DMn (Fig. 10b,c; Hawco et al., 2016; Heller et al., 2017). Nitrate-mediated Fe(II) oxidation might also contribute to the rapid decrease in $\mathrm{Fe}$ across the margin-ocean boundary in the Peruvian anoxic region (Scholz et al., 2016). In addition, Moffett (1997) demonstrated that the upper water column of the equatorial Pacific was characterized by slow Mn oxidation rates, which resulted in a relatively long residence time for Mn in surface waters, thereby facilitating long-range transport to the open ocean. Taken together, these observations indicate that the shelf sediments were a source of Fe but, in contrast to Mn, scavenging prevented its off shelf transport.

Because the Peru shelf waters are enriched in DMn, DCo and DFe as well as in ${ }^{228} \mathrm{Ra}$ (Fig. 10), we propose the use of ${ }^{228} \mathrm{Ra}$ as a tool to estimate the shelf to ocean fluxes of these key TEIs following Charette et al. (2016). Eddy-driven filaments may play a role in the extension of the shelf derived plume that extends towards the open ocean. However, the lateral extension of these features seems to be limited. Thomsen et al. (2016) observed filaments up to $79^{\circ} \mathrm{W}$ off Peru. Our high ${ }^{228} \mathrm{Ra}$ concentrations in surface waters extend up to $\sim 110^{\circ} \mathrm{W}$. As a result, even though the eddy-driven filaments may play a role, this mechanism is likely minor relative to horizontal diffusion and general circulation. The general ocean circulation in the eastern South Pacific, also called the Humboldt Current System or the Peru-Chile Current System, is dominated by several currents flowing parallel to the coast: (1) the Peru Oceanic Current (POC) and the Peru Coastal Current (PCC) contribute to the South Equatorial Current (SEC) flowing equatorward at the surface following the coast before turning offshore at around $15^{\circ} \mathrm{S}$, and (2) the subsurface Peru-Chile Undercurrent (PCUC), which flows southward near the shelf (Penven et al., 2005). Thus, assuming that the net shelf-ocean exchange over the $8000 \mathrm{~km}$ length-scale of our study is primarily driven by eddy diffusion, which we think it is satisfied due to the Meridional average circulation at $12^{\circ} \mathrm{S}$ (Penven et al., 2005), the shelf TEI flux can be estimated as follows:

$\mathrm{F}^{-\mathrm{TEI}_{\text {shelf }}}=\mathrm{F}-\mathrm{Ra}_{\text {shelf }} \times \mathrm{TEI} /{ }^{228} \mathrm{Ra}$

where F-Ra $\mathrm{a}_{\text {shelf }}$ is the total flux of ${ }^{228} \mathrm{Ra}$ from all coastal sources in the first $200 \mathrm{~m}$ derived from a global inverse model as discussed above (Kwon et al., 2014) and TEI/ ${ }^{228} \mathrm{Ra}$ corresponds to the slope of the best fit relationship between the dissolved TEI concentrations and ${ }^{228} \mathrm{Ra}$ observed in surface waters (Fig. 11). This approach allows us to estimate the flux of the dissolved TEI across the shelf-open ocean boundary, but may not equal the sum of all shelf inputs due to water column shelf processes such as biological uptake and scavenging removal of TEIs. The TEI $/{ }^{228} \mathrm{Ra}$ gradients along the offshore transect integrate the seasonal variability on the shelf. This method can be applied to all TEIs, from highly particle reactive to non-particle reactive TEIs, assuming that the main sources of TEI and ${ }^{228} \mathrm{Ra}$ are over the shelf. However, it is important to highlight that the calculated TEI flux represents the net dissolved shelf inputs, which do not necessarily reach the ocean interior due to varying degrees of TEI particle reactivity and biological cycling (Charette et al., 2016). In order to investigate the dissolved TEI $/{ }^{228} \mathrm{Ra}$ relationships within the shelf plume, we focused on samples located between the surface and the $26 \mathrm{~kg} \mathrm{~m}^{-3}$ isopycnal, where the highest ${ }^{228} \mathrm{Ra}$ activities were observed (Fig. 6). Shelf data are shown individually, while at the offshore stations we reported the weighted average concentration of samples from depths above the $26 \mathrm{~kg} \mathrm{~m}^{-3}$ density surface. The weighted average ${ }^{228} \mathrm{Ra}$ concentration decreases from station 5 to station 17. Note that station 9 displays a high ${ }^{228} \mathrm{Ra}$, as well as DMn, DCo, and DFe concentrations relative to the surrounding stations, which could potentially be related to the presence of an eddy as discussed in Section 3.2.

The upper water column DMn and ${ }^{228}$ Ra fell along two linear trend lines, each with relatively high $\mathrm{r}^{2}$ values (Fig. 11a). The shelf data had a slope of $6.0 \times 10^{-5} \mathrm{nmol}^{-1}$ atom $^{-1}\left(\mathrm{r}^{2}=0.73\right)$ with a DMn intercept of $1.4 \mathrm{nM}$. The offshore samples also followed a straight line with a $\mathrm{DMn} /{ }^{228} \mathrm{Ra}$ slope of $2.17 \times 10^{-4} \mathrm{nmol}$ atom ${ }^{-1}\left(\mathrm{r}^{2}=0.70\right)$ and an intercept close to zero. The former is the expected mixing relationship for shelf and upwelled water. The linearity is consistent with conservative mixing between nearshore and offshore waters, on timescales that are short compared to the 6-year half-life of ${ }^{228} \mathrm{Ra}$. It is possible that offshore data reflect the long term average shelf DMn and ${ }^{228} \mathrm{Ra}$ 


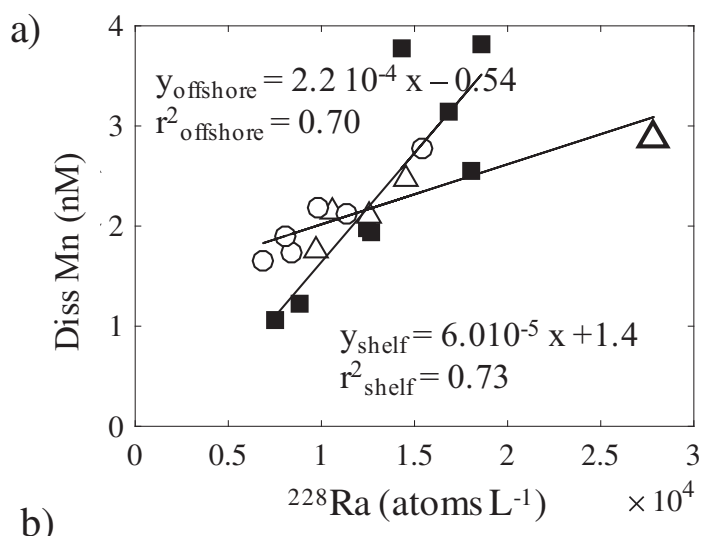

b)
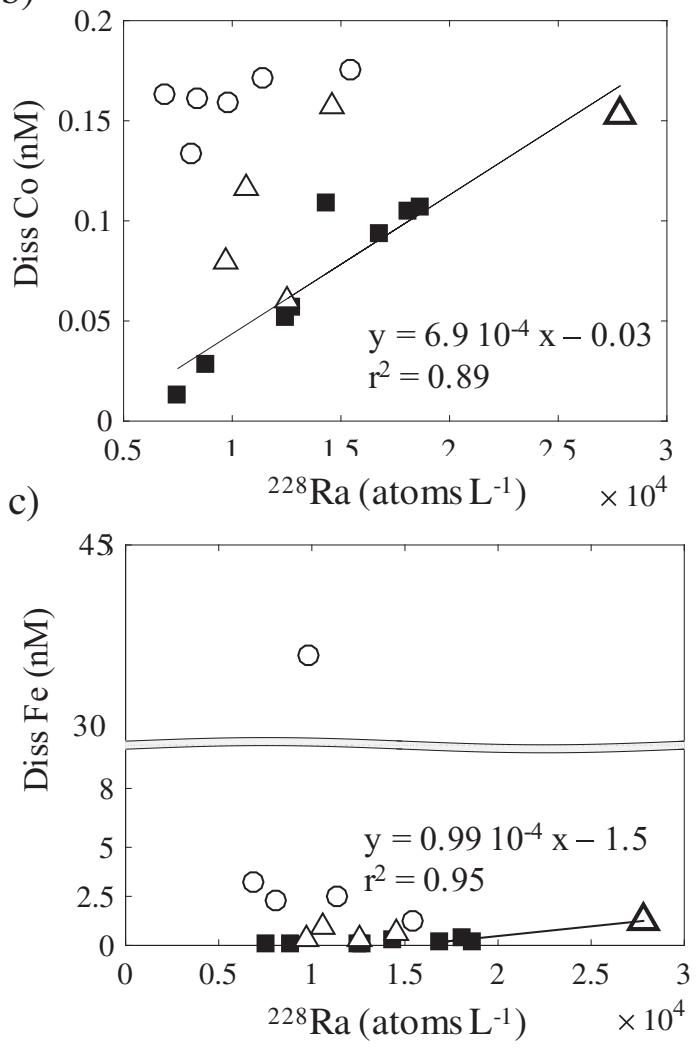

\footnotetext{
- Weighted concentrations offshore above $\sigma_{\theta}=26 \mathrm{~kg} / \mathrm{m}^{3}$

$\triangle$ Shelf concentrations above $\sigma_{3}=26 \mathrm{~kg} / \mathrm{m}^{3}$

$\triangle$ Station 3, $13 \mathrm{~m}$

Shelf concentrations below $\sigma_{3}=26 \mathrm{~kg} / \mathrm{m}^{3}$ and above $200 \mathrm{~m}$
}

Fig. 11. Dissolved Mn (a), dissolved Co (b), and dissolved Fe (c) concentrations as a function of ${ }^{228} \mathrm{Ra}$ concentrations for the upper water column across GP16. Offshore data (stations 1, 5-17) are presented as weighted averages while data over the shelf (stations 2-4) are plotted individually. The offshore weighted average concentrations (closed symbols) were based on data between the surface and the $26 \mathrm{~kg} \mathrm{~m}^{-3}$ isopycnal. Shelf station data are represented by open symbols; triangles are used for samples located between the surface and $26 \mathrm{~kg} \mathrm{~m}^{-3}$ isopycnal while circles are used for shelf samples located between $26 \mathrm{~kg} \mathrm{~m}^{-3}$ isopycnal and $200 \mathrm{~m}$.

inputs, or that along-shelf variability is significant such that we were not able to fully characterize the shelf endmember with our single shore-perpendicular transect. Alternatively, this may represent 3 endmember mixing, with near-shore shelf water mixing with a lower concentration upwelled water, and then with surface water whose chemical signature is far offshore.

Similar to DMn, the DCo concentrations measured in offshore samples also followed a linear trend with ${ }^{228} \mathrm{Ra}$ (slope $\mathrm{DCo} /{ }^{228} \mathrm{Ra}=6.94 \times 10^{-6} \mathrm{nmol}^{\text {atom }}{ }^{-1} ; \mathrm{r}^{2}=0.89$; Fig. 11b). However, only two samples collected over the shelf fell along this mixing curve, including the station 3 sample that displayed the highest ${ }^{228} \mathrm{Ra}$. Dissolved Co concentrations on the shelf relative to ${ }^{228} \mathrm{Ra}$ were higher than offshore, such that upwelling of high DCo/low ${ }^{228}$ Ra waters could account for this pattern (Hawco et al., 2016). However, contrary to DMn, no specific trend was observed between DCo and ${ }^{228} \mathrm{Ra}$ on the shelf, suggesting that DCo has different sources and/or sinks than ${ }^{228} \mathrm{Ra}$. Biological uptake, export, and/or remineralization of Co, as suggested by the linear correlation between DCo and dissolved phosphate along GP16 (Hawco et al., 2016), may also account for decoupling DCo and ${ }^{228} \mathrm{Ra}$ over the shelf. The conservative mixing line for the offshore data suggests no significant Co inputs with relatively slow scavenging removal of during offshore transport (Noble et al., 2012).

The $13 \mathrm{~m}$ sample from station 3 is the only one that displays both higher Fe and ${ }^{228} \mathrm{Ra}$ concentrations relative to offshore samples. Further, no specific trend was observed between DFe and ${ }^{228} \mathrm{Ra}$ over the shelf. Although $\mathrm{Fe}$ concentrations were highly variable over the shelf, the consistently higher shelf DFe concentrations suggest that there must be a positive shelf-ocean exchange of DFe. The variability likely reflects the wide range of $\mathrm{DFe}$ sources combined with a short transport length scale due to its affinity for particles. We therefore use the station 3 sample as an upper limit anchor for computing the $\mathrm{DFe} /{ }^{228} \mathrm{Ra}$ slope of $0.99 \times 10^{-4} \mathrm{nmol}_{\text {atoms }}{ }^{-1}\left(\mathrm{r}^{2}=0.94 ; \mathrm{n}=4\right.$; Fig. 11c). The steepness of the $\mathrm{DFe} /{ }^{228} \mathrm{Ra}$ trend relative to DCo and DMn highlights the fact that only a small fraction of the dissolved iron released from the shelf sediments is transported offshore, most likely due to scavenging processes.

\subsection{Shelf TEI fluxes}

The correlation between DMn and ${ }^{228}$ Ra over the GP16 transect to $109^{\circ} \mathrm{W}$ (station 17) suggests that Mn was transported over significant length scales into the open ocean (Fig. 11a). From Eq. (4) and the $\mathrm{DMn} /{ }^{228} \mathrm{Ra}$ slope observed in offshore waters, we derived a F-Mn $\mathrm{Mhelf}_{\text {she }}$ of $3300 \mu \mathrm{mol} \mathrm{m}^{-2} \mathrm{y}^{-1}$ (Table 1). This F-Mn $\mathrm{Mhelf}_{\text {sis }}$ is one order of magnitude higher than the Mn flux from the Western North Atlantic shelf $\left(220 \mu \mathrm{mol} \mathrm{m}{ }^{-2} \mathrm{y}^{-1}\right.$; Charette et al., 2016), but within the range of estimates of other shelf sedimentary Mn fluxes $\left(140 \mu \mathrm{mol} \mathrm{m}{ }^{-2} \mathrm{y}^{-1}\right.$, Landing and Bruland, 1987; $2900 \pm 1800 \mu \mathrm{mol} \mathrm{m}{ }^{-2} \mathrm{y}^{-1}$, McManus et al., 2012). Scholz et al. (2011) estimated a benthic Mn flux of $400 \mu \mathrm{mol} \mathrm{m}{ }^{-2} \mathrm{y}^{-1}$ at $85 \mathrm{~m}$ on the Peru continental shelf for the same season as the GP16 transect (Nov-Dec 2008). The higher estimates reported here could be explained by spatial/temporal variability or the presence of other important shelf sources of Mn, such as river inputs and submarine groundwater discharge that are not accounted for in other estimates (e.g. Scholz et al., 2011).

Table 1

Sedimentary dissolved Manganese (Mn), dissolved Cobalt (Co) and dissolved Iron (Fe) fluxes from the Peruvian continental shelf.

\begin{tabular}{|c|c|c|c|c|}
\hline & $\begin{array}{l}\mathrm{TEI} /{ }^{228} \mathrm{Ra} \text { gradient } \\
\left(\mathrm{nmol} \text { atom }^{-1}\right)\end{array}$ & $\begin{array}{l}\text { F-TEI }_{\text {shelf }} \\
\left(\mu \mathrm{mol} \mathrm{m}{ }^{-2} y^{-1}\right)\end{array}$ & $\begin{array}{l}{ }^{\mathrm{a}} \mathrm{F}-\mathrm{TEI}_{\text {shelf }} \\
\left(\mathrm{mol} \mathrm{y}^{-1}\right)\end{array}$ & $\begin{array}{l}{ }^{\mathrm{b}} \mathrm{F}-\mathrm{TEI}_{\text {dust }} \\
\left(\mathrm{mol} \mathrm{y}^{-1}\right)\end{array}$ \\
\hline Mn & $2.2 \times 10^{-4}$ & 3300 & $3.6 \times 10^{8}$ & $8.8 \times 10^{7 c}$ \\
\hline Co & $6.9 \times 10^{-6}$ & 100 & $1.1 \times 10^{7}$ & $7.7 \times 10^{5 \mathrm{~d}}$ \\
\hline $\mathrm{Fe}$ & $0.99 \times 10^{-4}$ & 1500 & $1.6 \times 10^{8}$ & $3.4 \times 10^{8 \mathrm{e}}$ \\
\hline
\end{tabular}

${ }^{\text {a }}$ A continental shelf area of $1.1 \times 10^{11} \mathrm{~m}^{2}$ is considered for the grid $0-20^{\circ} \mathrm{S} 70-90^{\circ} \mathrm{W}$ between 0-200 $\mathrm{m}$ depth (estimated from ETOPO1 1-minute gridded elevation data).

${ }^{b}$ Dissolved aerosol flux to the South Pacific Ocean.

${ }^{\mathrm{c}} \mathrm{F}-\mathrm{Mn}_{\text {dust }}$ is based on an abundance in the upper crust of $1.09 \times 10^{-5} \mathrm{~mol} \mathrm{~g}^{-1}$ (Taylor and McLennan, 1985) and a 30\% fractional solubility in dust (van Hulten et al., 2016).

${ }^{\mathrm{d}} \mathrm{F}_{-}-\mathrm{Co}_{\text {dust }}$ is based on an abundance in the upper crust of $2.86 \times 10^{-7} \mathrm{~mol} \mathrm{~g}^{-1}$ (McLennan, 2001) and a 10\% fractional solubility in dust (Shelley et al., 2012).

${ }^{\mathrm{e}} \mathrm{F}_{-} \mathrm{Fe}_{\text {dust }}$ is based on an abundance in the upper crust of $6.3 \times 10^{-4} \mathrm{~mol} \mathrm{~g}^{-1}$ (Taylor and McLennan, 1985) and a 2\% fractional solubility in dust (Jickells and Spokes, 2001). 
The $\mathrm{F}-\mathrm{Co}_{\text {shelf }}$ determined using the same method was estimated at $100 \mu \mathrm{mol} \mathrm{m}{ }^{-2} \mathrm{y}^{-1}$, which is about twice as high as the broad Western North Atlantic margin input (Charette et al., 2016). Similar to DMn, DCo was transported well beyond the shelf into the open ocean (Fig. 11b). The high F-Co ${ }_{\text {shelf }}$ is not particularly surprising given the presence of the OMZ, which serves to enhance the coastal DCo flux (Hawco et al., 2016). Assuming that most of the lithogenic sediments from the Peruvian shelf originate from rivers (Scheidegger and Krissek, 1982), Hawco et al. (2016) combined the particulate riverine flux with the difference between the crustal and buried sediment $\mathrm{Co} / \mathrm{Al}$ ratios on the Peruvian margin (Böning et al., 2004) to calculate a total coastal DCo flux from the South American shelf of $110-200 \mu \mathrm{mol} \mathrm{m}^{-2} \mathrm{y}^{-1}$.

We estimated the $\mathrm{F}_{-} \mathrm{Fe}_{\text {shelf }}$ from the Peruvian shelf to be $1500 \mu \mathrm{mol} \mathrm{m}{ }^{-2} \mathrm{y}^{-1}$ (Table 1). However, we acknowledge that the uncertainty on this $\mathrm{F}-\mathrm{Fe}_{\text {shelf }}$ estimate is much higher than that for $\mathrm{Mn}$ and Co because of the single high DFe (and ${ }^{228} \mathrm{Ra}$ ) value over the shelf, which drives the $\mathrm{DFe} /{ }^{228} \mathrm{Ra}$ trend. Much higher $\mathrm{Fe}(\mathrm{II})^{+}$fluxes have been previously reported for the OMZ of the Peruvian shelf $(\sim 80-500 \mathrm{~m})$; benthic chamber fluxes were up to $316 \times 10^{3} \mu \mathrm{mol} \mathrm{m} \mathrm{m}^{-2} \mathrm{y}^{-1}$, while pore water diffusion models yielded values of $88.3 \times 10^{3} \mu \mathrm{mol} \mathrm{m}{ }^{-2} \mathrm{y}^{-1}$ (Noffke et al., 2012; Scholz et al., 2011). We note that the benthic diffusive Mn flux estimated by Scholz

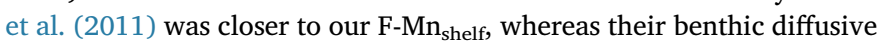
Fe flux was much greater than our $\mathrm{F}_{-} \mathrm{Fe}_{\text {shelf }}$ estimate, which is probably due to the fact that Mn(II) oxidizes more slowly than Fe(II) (Stumm and Morgan, 1996), and that a large fraction of DFe is oxidized near the sediment-water interface. Noffke et al. (2012) showed that the Fe flux was the greatest on the shelf at $85 \mathrm{~m}$, moderate between 250 and $600 \mathrm{~m}$, and negligible below this depth. Since the radium enrichment was limited in the upper $\sim 200 \mathrm{~m}$ of the water column (depending on the $26 \mathrm{~kg} \mathrm{~m}^{-3}$ isopycnal depth; Fig. 6), there was no strong evidence of sedimentary Fe inputs between $200 \mathrm{~m}$ and $600 \mathrm{~m}$ during GP16. However, these other studies do not take into account water column removal processes, thus they are likely not representative of the actual input of shelf material from the shelf reaching the open ocean. When removal processes were taken into account, shelf-ocean Fe fluxes range from $160 \mu \mathrm{mol} \mathrm{m}^{-2} \mathrm{y}^{-1}$ in the Western North Atlantic shelves (Charette et al., 2016) to $660 \mu \mathrm{mol} \mathrm{m}{ }^{-2} \mathrm{y}^{-1}$ near the Antarctic Peninsula shelf (Dulaiova et al., 2009) to $1570 \mu \mathrm{mol} \mathrm{m}^{-2} \mathrm{y}^{-1}$ from the Crozet Island shelves (Charette et al., 2007). The F-Fe shelf $_{\text {estimated for }}$ our GP16 study region remains in the upper range of published shelf Fe flux estimates.

Because of the very specific features of the Peru coastal region such as the strong coastal upwelling, OMZ, and narrow shelf, the estimates of

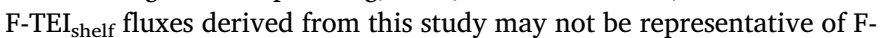
$\mathrm{TEI}_{\text {shelf }}$ fluxes from other continental margins. We thus decided to limit extrapolation of our F-TEI shelf $_{\text {flux estimates to the eastern subtropical }}$ South Pacific Ocean. Assuming a shelf area of $1.1 \times 10^{11} \mathrm{~m}^{2}$ between $0-20^{\circ} \mathrm{S}$ and $70-90^{\circ} \mathrm{W}$ (estimated from ETOPO1 1-minute gridded elevation data), we calculate a F-Mn $\mathrm{Mhelf}_{\text {of }} 3.6 \times 10^{8} \mathrm{~mol} \mathrm{y}^{-1}$, a F-Co $\mathrm{Co}_{\text {shelf }}$ of $1.1 \times 10^{7} \mathrm{~mol} \mathrm{y}^{-1}$, and a F-Fe shelf of $1.6 \times 10^{8} \mathrm{~mol} \mathrm{y}^{-1}$ (Table 1 ). The total dust deposition to the oceans was estimated at $450 \mathrm{Tg} \mathrm{y}^{-1}$; $6 \%$ of this is deposited over the South Pacific Ocean, or $2.7 \times 10^{13} \mathrm{~g} \mathrm{y}^{-1}$ (Jickells et al., 2005). The TEIs flux from aerosol deposition $\left(\mathrm{F}_{-}-\mathrm{TEI}_{\mathrm{dust}}\right)$ to the South Pacific Ocean is then estimated considering the abundance in the upper continental crust and the fractional solubility in dust of each element (Table 1). This results in a F-Mn dust $_{\text {of }} 8.8 \times 10^{7} \mathrm{~mol} \mathrm{y}^{-1}, \mathrm{~F}_{-} \mathrm{Co}_{\text {dust }}$ of $7.7 \times 10^{5} \mathrm{~mol} \mathrm{y}^{-1}$, and a F$\mathrm{Fe}_{\text {dust }}$ of $3.4 \times 10^{8} \mathrm{~mol} \mathrm{y}^{-1}$. The input of $\mathrm{Fe}$ from the eastern South Pacific continental shelf between $0-20^{\circ} \mathrm{S}$ is thus about the same order of magnitude as the aerosol deposition over the entire South Pacific basin. Furthermore, the inputs of $\mathrm{Co}$ and $\mathrm{Mn}$ from aerosol deposition represent only $\sim 7 \%$ and $\sim 24 \%$ of the fluxes from the eastern South Pacific continental shelf, respectively.

The shelf TEI flux gauge approach (Eq. (4)) relies on a model-based estimate of the shelf ${ }^{228} \mathrm{Ra}$ input from the Peruvian margin, which was in good agreement with a simple box model-derived flux that drew on historical and new data presented herein. These estimates represent long-term averages, and are supported by recent work that has shown that terrestrial and shelf inputs of ${ }^{228} \mathrm{Ra}$ to the upper Atlantic Ocean are at steady-state (Charette et al., 2015). On the other hand, the data collected during GP16 represent a 'snapshot' of shelf TEI and ${ }^{228} \mathrm{Ra}$ distribution, and we know from limited historical data that ${ }^{228} \mathrm{Ra}$ may vary seasonally over the shelf (Fig. 5). Differences in TEI concentrations in the Peruvian coastal upwelling region have also been highlighted between GP16 and previous studies at $5-10^{\circ} \mathrm{S}$, which reported lower concentrations of DCo (Hawco et al., 2016; Saito et al., 2004) and DFe (Bruland et al., 2005; Resing et al., 2015). In addition to variability in terrestrial runoff, the Peruvian coastal upwelling is strongly seasonal, due in part to wind stress variations, with the strongest winds leading to the greatest thermocline depth amplitude in June and the lowest magnitude winds in January (Kessler, 2006). Spatial and temporal variations as a result of the mesoscale dynamics may also impact the TEI fluxes (Penven et al., 2005). Dissolved oxygen fluctuations due to ENSO have also been shown to play an important role on deposition and mobilization of $\mathrm{Mn}$ and Fe (Scholz et al., 2011). In addition, Scholz et al. (2014) discussed the relationship between oxygen concentration in both the water column and bottom water, and the export of Fe from the continental shelf over the past 140,000 years, and suggested that future deoxygenation of the Peru upwelling waters may lead to a decrease in Fe availability. However, these authors acknowledged that other upwelling areas associated with a less intense OMZ, such as the southeast Atlantic, may respond differently to deoxygenation. Hence, our application here of TEI $/{ }^{228} \mathrm{Ra}$ relationships based on GP16 data alone may not be representative of long-term averages, which introduces uncertainty with to the shelf flux estimates presented above. Additional process studies would be required to fully assess the seasonal variability in the TEI $/{ }^{228} \mathrm{Ra}$ relationship for the Peruvian shelf.

\subsection{Slope TEI fluxes}

Continental slopes receive substantial quantities of particulate material from the upper ocean as well as gravity-driven sediment flows from the shelf (e.g. Lampitt et al., 1995; Walsh and Nittrouer, 1999). However, material inputs to the open ocean from slope sediments remain poorly constrained. Lam and Bishop (2008) reported substantial lateral advective inputs of labile particulate Fe and Mn from the upper continental slope to the high-nutrient low-chlorophyll (HNLC) North Pacific Ocean. Elevated DMn concentrations near the Mauritanian coast were well correlated with ${ }^{228} \mathrm{Ra}$, indicative of recent contact with shelf/ slope sediments (Hatta et al., 2015). The breaking and dissipation of internal waves along the continental slope may generate sediment resuspension and maintain a mid-water nepheloid layer (Cacchione and Drake, 1986). When internal waves break over a very steep slope, such as the Peruvian continental slope, the internal waves are very energetic and the energy is concentrated within a narrow band, causing intense sediment resuspension (Cacchione and Wunsch, 1974). High concentrations of particulate aluminum (Al), titanium (Ti), Fe, and Mn were observed near the seafloor at station 5 located over the slope during GP16 (Lee et al. in this issue). The high dissolved TEI and ${ }^{228} \mathrm{Ra}$ concentrations in the plume attached to the Peruvian continental slope might then be derived from reducing slope sediments. Strong zonal currents were observed in the Tropical Pacific Ocean at 1000 and $1500 \mathrm{~m}$, however, they disappear east of $110^{\circ} \mathrm{W}$ (Cravatte et al., 2012), which suggests that the dissolved TEIs and ${ }^{228}$ Ra were likely transported away from the slope via turbulent diffusion rather than advection. Once released into the water column, dissolved TEIs, including radium, may then be transported along isopycnals towards the open ocean (Sarmiento and Rooth, 1980; Sarmiento et al., 1982). As a consequence, in addition to remineralization or dissolution of sinking particles, lateral transport of materials from the continental slope into the deep ocean should be considered in global TEI budgets. In addition, 

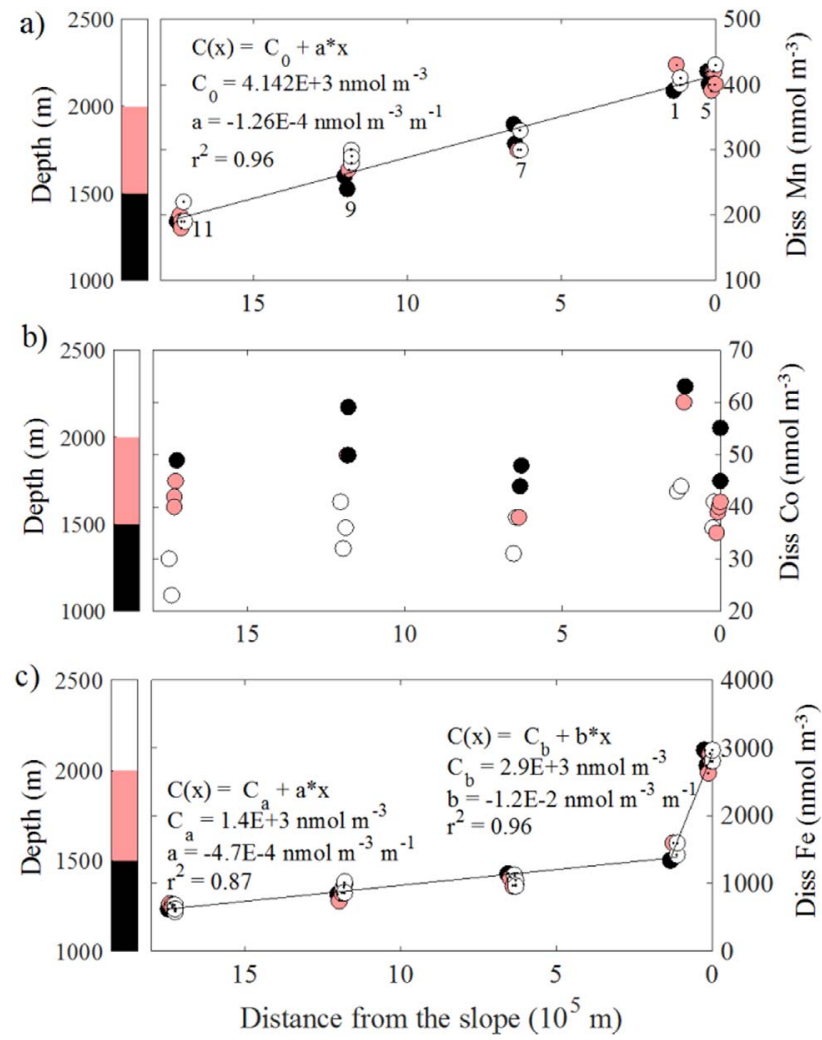

Fig. 12. Distribution of dissolved Mn (a), dissolved Co (b), and dissolved Fe (c) concentrations between $1000 \mathrm{~m}$ and $2500 \mathrm{~m}$ for stations 1, 5-11 as a function of distance from the slope. The depth range of the samples is indicated by the color of the symbols. The station numbers are reported next to the data symbols in figure a.

vertical mixing and upwelling may deliver essential micronutrients from the continental margins to surface waters where they can sustain primary productivity (Lam and Bishop, 2008).

Along GP16, there was a broad mid-depth $(\sim 1000-2500 \mathrm{~m})$ enrichment in DMn near the Peruvian margin, which matched the subsurface distribution of ${ }^{228} \mathrm{Ra}$ (Fig. 7), suggesting a significant input of DMn from continental slope sediments. Dissolved Mn decreased monotonically from the Peru margin to $1800 \mathrm{~km}$ offshore, a pattern that suggests conservative mixing in the absence of a DMn inputs from sinking particle remineralization or dissolution along the GP16 transect (Fig. 12a). In contrast, DCo was relatively constant and homogeneous over this depth range (Fig. 12b). Thus, the input of DCo from the continental slope to intermediate and deep waters appears to be relatively minor, at least compared to water column sources and sinks. At the station closest to the Peru margin, high ${ }^{228} \mathrm{Ra}$ activities below $1000 \mathrm{~m}$ were positively correlated with DFe concentrations, suggesting that the $\mathrm{Fe}$ distribution is influenced by slope sediment inputs (Fig. 12c). However, there was a sharp decrease in DFe between the margin and $100 \mathrm{~km}$ offshore (station 1), which indicates limited offshore transport due to rapid scavenging processes. However, there was still a discernible lateral gradient in mid water column DFe concentrations from $150-1800 \mathrm{~km}$ offshore that might be explained by a net lateral input of $\mathrm{Fe}$ from the slope sediments (Fig. 12c). This middepth $\mathrm{Fe}$ enrichment is also associated with a low $\delta^{56} \mathrm{Fe}$ signature persistent over $\sim 4000 \mathrm{~km}$ offshore (John et al., in this issue). This unexpected deep Fe feature led John et al., (in this issue) to employ a numerical model to try and reproduce the high DFe and low $\delta^{56} \mathrm{Fe}$ plumes. They concluded that the DFe was the result of Fe released from the upper slope $(100-1000 \mathrm{~m})$ followed by scavenging onto sinking particles and remineralization deeper in the water column. However, the authors acknowledged that they could not rule out a slope sediment DFe source in a form more resistant to scavenging.
Table 2

Sedimentary dissolved Manganese (Mn), dissolved Cobalt (Co) and dissolved Iron (Fe) fluxes from the Peruvian continental slope.

\begin{tabular}{llll}
\hline & $\begin{array}{l}\text { TEI gradient } \\
\left(\mathrm{nmol} \mathrm{m}^{-3} \mathrm{~m}^{-1}\right)\end{array}$ & $\begin{array}{l}\mathrm{F}^{-T E I_{\text {slope }}} \\
\left(\mu \mathrm{mol} \mathrm{m}^{-2} \mathrm{y}^{-1}\right)\end{array}$ & $\begin{array}{l}{ }^{\mathrm{a}} \mathrm{F}-\mathrm{TEI}_{\text {slope }} \\
\left(\mathrm{mol} \mathrm{y}^{-1}\right)\end{array}$ \\
\hline $\mathrm{Mn}$ & $1.3 \times 10^{-4}$ & 6.4 & $1.3 \times 10^{6}$ \\
$\mathrm{Co}$ & - & - & $1.3 \times 10^{8}$ \\
$\mathrm{Fe}_{1}(0-100 \mathrm{~km})$ & $1.2 \times 10^{-2}$ & 590 & $5.4 \times 10^{6}$ \\
$\mathrm{Fe}_{2}(150-1800 \mathrm{~km})$ & $4.7 \times 10^{-4}$ & 24 & \\
\hline
\end{tabular}

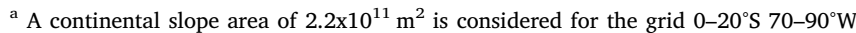
between 1000-2500 $\mathrm{m}$ depth (estimated from ETOPO1 1-minute gridded elevation data)

The TEI fluxes (F-TEI $I_{\text {slope }}$ ) from the Peruvian slope sediments can be derived from the horizontal TEI gradients (dTEI/dx; Fig. 12), the coefficient of eddy diffusivity $\left(\mathrm{K}_{\mathrm{h}}\right)$, and the inclination of the slope $(\theta)$ as follows:

F-TEI $_{\text {slope }}=\mathrm{K}_{\mathrm{h}} \sin \theta \mathrm{dTEI} / \mathrm{dx}$

This model assumes a constant TEI and ${ }^{228}$ Ra source from the slope and thus that TEI gradients and $\mathrm{K}_{\mathrm{h}}$ are at steady state, assumptions we believe are likely satisfied due to lack of seasonal forcing mechanisms in the deep ocean. We neglect any loss due to vertical mixing, and assume no advection orthogonal to the margin.

There was no significant lateral gradient in DCo, hence the slope sediment DCo flux is negligible relative to other processes supplying DCo to the mid water column (Fig. 12b). The product of the DMn gradients with the ${ }^{228} \mathrm{Ra}$-derived $\mathrm{K}_{\mathrm{h}}$ resulted in a $\mathrm{F}-\mathrm{Mn}_{\text {slope }}$ of $6.4 \mu \mathrm{mol} \mathrm{m}{ }^{-2} \mathrm{y}^{-1}$, which represents $\sim 0.2 \%$ of $\mathrm{F}-\mathrm{Mn}_{\text {shelf. }}$ Fe fluxes can be estimated for within $100 \mathrm{~km}$ of the slope $\left(\mathrm{F}_{1}-\mathrm{Fe}_{\text {slope }}\right.$ of $590 \mu \mathrm{mol} \mathrm{m}^{-2} \mathrm{y}^{-1}$; between the slope and station 1) and further afield $\left(\mathrm{F}_{2}-\mathrm{Fe}_{\text {slope }}\right.$ of $24 \mu \mathrm{mol} \mathrm{m} \mathrm{m}^{-2} \mathrm{y}^{-1}$; stations 1-11; Table 2). The $\mathrm{F}_{2}-\mathrm{Fe}_{\text {slope }}$ (50-1800 km away from the slope) is likely to be more representative of the net Fe input to the interior Pacific Ocean basin; this flux is $\sim 4.2 \%$ of $\mathrm{F}_{1}-\mathrm{Fe}_{\text {slope }}$ and $1.7 \%$ of $\mathrm{F}-\mathrm{Fe}_{\text {shelf }}$.

Once released into the deep ocean, ligands may stabilize dissolved Fe through complexation, thereby limiting its removal from the water column via oxidation or scavenging removal by sinking particles (Elrod et al., 2004). Complexation is also important for DMn (Madison et al., 2013). Higher organic ligand concentrations were generally observed along GP16 compared to the Atlantic Ocean; in particular, a plume of strong ligand L1 extended from the margin between $1000-3000 \mathrm{~m}$ to as far as $90^{\circ} \mathrm{W}$ (Buck et al. in this issue). In addition, Fe can be transported over long distance as colloids, which may account for as much as half of the dissolved Fe pool in the deep ocean (Hunter and Boyd, 2007; von der Heyden and Roychoudhury, 2015), as long as they do not aggregate and sink (Fitzsimmons et al., 2014).

The unique combination of the steepness of the Peruvian continental slope and the presence of an intense OMZ over the upper slope may lead to distinct TEI fluxes that may not be representative on a global scale; therefore, we extrapolated the $\mathrm{F}_{-}-\mathrm{TEI}_{\text {slope }}$ estimates to the slope area between $0-20^{\circ} \mathrm{S}$ and $70-90^{\circ} \mathrm{W}$ (estimated from ETOPO1 1min gridded elevation data). For the depth range of $1000-2500 \mathrm{~m}$, the slope area is $2.2 \times 10^{11} \mathrm{~m}^{2}$, which produces a scaled $\mathrm{F}-\mathrm{Mn}_{\text {slope }}$ of $1.3 \times 10^{6} \mathrm{~mol} \mathrm{y}^{-1}$, a $\mathrm{F}_{1}-\mathrm{Fe}_{\text {slope }}$ of $1.3 \times 10^{8} \mathrm{~mol} \mathrm{y}^{-1}$, and a $\mathrm{F}_{2}-\mathrm{Fe}_{\text {slope }}$ of $5.4 \times 10^{6} \mathrm{~mol} \mathrm{y}^{-1}$. When comparing to the total shelf TEI fluxes for the same grid, the F-Mn $-\mathrm{n}_{\text {slope }}$ represents $<1 \%$ of the $\mathrm{F}-\mathrm{Mn}_{\text {shelf }}$ while the $\mathrm{F}_{1}-\mathrm{Fe}_{\text {slope }}$ is about the same order of magnitude as the $\mathrm{F}-\mathrm{Fe}_{\text {shelf }}$. The higher TEI fluxes released by continental shelves could be in part due to the decrease in grain size sediment across the Peru margin, although an unusual pattern was observed at $13^{\circ} \mathrm{S}$ with anomalous fine-grained sediments found in the upper-slope $(<1000 \mathrm{~m}$ water depth) due to local influences (Krissek et al., 1980). The greater permeability of large grain-sized sediment deposited on the continental shelf would thus favor a pore-water exchange mechanism (Huettel et al., 2014). Further, it is possible that bio-irrigation is more pronounced at shallower depths 
(Noffke et al., 2012). Finally, the lower fluxes in deeper water may simply reflect a lower particulate rain of TEIs from above. The hydrothermal input of $\mathrm{Fe}$ and $\mathrm{Mn}$ from the East Pacific Rise to the ocean interior were estimated at $4 \times 10^{9} \mathrm{~mol} \mathrm{y}^{-1}$ and $1.3 \times 10^{9} \mathrm{~mol} \mathrm{y}^{-1}$, respectively (Resing et al., 2015). The hydrothermal Mn flux is on par with our combined shelf and slope flux while the hydrothermal Fe flux is three orders of magnitude greater. However, we note that the continental margin TEI fluxes were extrapolated to a limited area; thus, shelf and slope sediments account for a substantial flux of TEIs to the deep ocean, though further investigations are needed to better constrain the spatial and temporal variations of the continental margin derived material inputs.

\section{Conclusions}

Radium isotopes were used to identify major water masses $\left({ }^{226} \mathrm{Ra}\right)$ and quantify shelf and slope TEI fluxes $\left({ }^{228} \mathrm{Ra}\right)$ in the Eastern Tropical South Pacific Ocean. The ${ }^{226} \mathrm{Ra}$ distribution below $2000 \mathrm{~m}$ was characterized by an east-west asymmetry, with high ${ }^{226} \mathrm{Ra}$ activities in the east versus low ${ }^{226} \mathrm{Ra}$ activities in the west, largely the result of northward (AABW) and southward (PDW) flowing source waters, respectively. Elevated ${ }^{228} \mathrm{Ra}$ activities were measured in the upper $200 \mathrm{~m}$ over the entire transect, a distance of $8500 \mathrm{~km}$, as a result of sedimentary inputs from the continental shelf. A deep ${ }^{228} \mathrm{Ra}$ plume was observed at $\sim 1000-2500 \mathrm{~m}$ as far as $600 \mathrm{~km}$ away from the margin, evidence for the important yet underappreciated role of continental slopes as sedimentary TEI sources to the deep ocean. To our knowledge, this study is one of the few to provide direct estimates of TEI fluxes from the continental slope.

Shelf sediments were likely the main source of DMn to the upper ocean off Peru as demonstrated by the linear DMn $/{ }^{228} \mathrm{Ra}$ relationship observed both in shelf and offshore surface waters. A linear DCo/ ${ }^{228} \mathrm{Ra}$ relationship was also observed in surface waters off Peru; however, no specific DCo $/{ }^{228} \mathrm{Ra}$ trend was seen in shelf waters, suggesting that Co has multiple sources/sinks over the shelf (other than sedimentary). A sharp $\mathrm{DFe} /{ }^{228} \mathrm{Ra}$ gradient was observed near the margin suggesting a rapid removal of $\mathrm{Fe}$. The $\mathrm{DMn} /{ }^{228} \mathrm{Ra}$ ratio was relatively constant whereas the $\mathrm{DCo} /{ }^{228} \mathrm{Ra}$ and $\mathrm{DFe} /{ }^{228} \mathrm{Ra}$ relationships over the shelf were more complex and variable. This variability, including that shown by the historical ${ }^{228} \mathrm{Ra}$ data, highlights the need to investigate the sensitivity of margin TEI fluxes due to changes in regional environmental conditions. The variable ${ }^{228} \mathrm{Ra}$ may also reflect the passage of transient eddies with variable fractions of offshore, upwelled, and coastal components.

Radium-228 was used as a sedimentary flux gauge to estimate the ocean input of dissolved TEIs from the continental margin. We estimated that the Peru continental shelf releases $3300 \mu \mathrm{mol} \mathrm{m}^{-2} \mathrm{y}^{-1}$ of DMn, $100 \mu \mathrm{mol} \mathrm{m}{ }^{-2} \mathrm{y}^{-1}$ of DCo, and $1500 \mu \mathrm{mol} \mathrm{m}{ }^{-2} \mathrm{y}^{-1}$ of DFe to the ocean off Peru. When extrapolated to the eastern South Pacific, the DFe released by the sediments from the continental margin appeared on par with the South Pacific aerosol DFe inputs, while the shelf sediment derived DMn and DCo fluxes were $\sim 4$ and $\sim 14$ times higher than the DMn and DCo aerosol inputs, respectively. Corresponding estimates of the DFe flux rates from the continental slope are of the same order of magnitude as the input of DFe released by the shelf. Conversely, the Peru continental slope was not a significant source of DCo and seemed to be only a minor source of DMn ( $<1 \%$ of the shelf DMn flux). Nonetheless, once released into deep waters, Mn and Fe may be maintained in the dissolved phase by ligands and as colloids, thus facilitating lateral transport over basin-scale distances where they may play a significant role in open ocean biogeochemical cycles.

Our study provides evidence that lateral transport of sediment derived TEIs from continental margins, including shelves and slopes, play an important role in open ocean TEI budgets and biogeochemistry. The Peruvian continental slope plays a greater role in the release of TEIs than other continental slopes such as in the western North Atlantic
(Charette et al., 2015), which could be the result of intense primary production seaward of the shelf break (Jahnke, 2010; Pennington et al., 2006). Our findings agree with recent work from Letscher et al. (2016) that emphasizes that ocean biogeochemistry is not solely controlled by vertical processes, and that lateral transport from continental margins are an important source of nutrients to the subtropical ocean gyres. In addition, there may be seasonal and interannual variability in TEI fluxes from the continental shelf, as evidenced by variability in ${ }^{228} \mathrm{Ra}$ activities between our study and historical values from the Peruvian margin. Establishing the mechanisms driving this variability requires further investigation in order to better constrain the shelf TEI source to the open ocean.

\section{Acknowledgements}

The authors would like to thank the chief scientists of the GP16 cruise J. Moffet and C. German. The authors gratefully acknowledge the Captain and crew members of the $R / V$ Thomas Thompson. We are especially thankful to the members of the in-situ pump team D. Ohnemus, E. Black, S. Nicholas and S. Pike. The authors are grateful to E.Y. Kwon for sharing her shelf-derived ${ }^{228}$ Ra flux from the inverse model. We thank Evelyne Garçon for technical assistance at the LSM underground laboratory. The authors would like to thank the anonymous reviewers for their comments. The WHOI postdoctoral scholar V. Sanial was supported by the Center for Marine and Environmental Radioactivity (CMER). This project was funded by the NSF Chemical Oceanography program under grant numbers OCE-1232669 to M.A.C., OCE-1231211 to W.S.M., OCE-1237011 to JAR, OCE-1237034 to PNS, and OCE-1235124 to DEH. This is JISAO Publication 2016-01-51 and PMEL publication \#4589.

\section{References}

Albani, S., Mahowald, N.M., Perry, A.T., Scanza, R.A., Zender, C.S., Heavens, N.G., Maggi, V., Kok, J.F., Otto-Bliesner, B.L., 2014. Improved dust representation in the Community Atmosphere Model. J. Adv. Model. Earth Syst. 6, 541-570. http://dx.doi. org/10.1002/2013MS000279.

Böning, P., Brumsack, H.-J., Böttcher, M.E., Schnetger, B., Kriete, C., Kallmeyer, J., Borchers, S.L., 2004. Geochemistry of Peruvian near-surface sediments. Geochim. Cosmochim. Acta 68 (21), 4429-4451. http://dx.doi.org/10.1016/j.gca.2004.04. 027.

Bowman, K.L., Hammerschmidt, C.R., Lamborg, C.H., Swarr, G.J., Agather, A.M., 2016. Distribution of mercury species across a zonal section of the eastern tropical South Pacific Ocean (U.S. GEOTRACES GP16). Mar. Chem. 186, 156-166. http://dx.doi. org/10.1016/j.marchem.2016.09.005.

Boyd, P.W., Ellwood, M.J., 2010. The biogeochemical cycle of iron in the ocean. Nat. Geosci. 3 (10), 675-682. http://dx.doi.org/10.1038/ngeo964.

Broecker, W.S., Li, Y.H., Cromwell, J., 1967. Radium-226 and radon-222: concentration in Atlantic and Pacific Oceans. Science 158 (3806), 1307-1310. http://dx.doi.org/ 10.1126/science.158.3806.1307.

Bruland, K.W., Lohan, M.C., 2003. Controls of trace metals in seawater. In: Treatise on Geochemistry. 6. pp. 625. http://dx.doi.org/10.1016/B0-08-043751-6/06105-3.

Bruland, K.W., Rue, E.L., Smith, G.J., DiTullio, G.R., 2005. Iron, macronutrients and diatom blooms in the Peru upwelling regime: brown and blue waters of Peru. Mar. Chem. 93 (2-4), 81-103. http://dx.doi.org/10.1016/j.marchem.2004.06.011.

Buck, K.N., Sohst, B., Sedwick, P., (in this issue) 2017. Iron-binding organic ligands in the Eastern Tropical Pacific.

Cacchione, D.A., Drake, D.E., 1986. Nepheloid layers and internal waves over continental shelves and slopes. Geo-Mar. Lett. 6 (3), 147-152. http://dx.doi.org/10.1007/ BF02238085.

Cacchione, D., Wunsch, C., 1974. Experimental study of internal waves over a slope. J. Fluid Mech. 66 (2), 223-239. http://dx.doi.org/10.1017/S0022112074000164.

Chaigneau, A., Pizarro, O., 2005. Eddy characteristics in the eastern South Pacific. J. Geophys. Res. 110 (C6), C06005. http://dx.doi.org/10.1029/2004JC002815.

Chan, L.H., Edmond, J.M., Stallard, R.F., Broecker, W.S., Chung, Y.C., Weiss, R.F., Ku, T.L., 1976. Radium and barium at GEOSECS stations in the Atlantic and Pacific. Earth Planet. Sci. Lett. 32 (2), 258-267. http://dx.doi.org/10.1016/0012-821X(76) 90066-2.

Charette, M.A., Buesseler, K.O., Andrews, J.E., 2001. Utility of radium isotopes for evaluating the input and transport of groundwater-derived nitrogen to a cape cod estuary. Limnol. Oceanogr. 46 (2), 465-470. http://dx.doi.org/10.4319/1o.2001.46. 2.0465 .

Charette, M.A., Gonneea, M.E., Morris, P.J., Statham, P., Fones, G., Planquette, H., Salter, I., Garabato, A.N., 2007. Radium isotopes as tracers of iron sources fueling a Southern Ocean phytoplankton bloom. Deep-Sea Res. II Top. Stud. Oceanogr. 54 (18-20), 
1989-1998. http://dx.doi.org/10.1016/j.dsr2.2007.06.003.

Charette, M.A., Morris, P.J., Henderson, P.B., Moore, W.S., 2015. Radium isotope distributions during the US GEOTRACES North Atlantic cruises. Mar. Chem. 177 (Part 1), 184-195. http://dx.doi.org/10.1016/j.marchem.2015.01.001.

Charette, M.A., Lam, P.J., Lohan, M.C., Kwon, E.Y., Hatje, V., Jeandel, C., Shiller, A.M., Cutter, G.A., Thomas, A., Boyd, P.W., Homoky, W.B., Milne, A., Thomas, H., Andersson, P.S., Porcelli, D., Tanaka, T., Geibert, W., Dehairs, F., Garcia-Orellana, J., 2016. Coastal ocean and shelf-sea biogeochemical cycling of trace elements and isotopes: lessons learned from GEOTRACES. Phil. Trans. R. Soc. A 374 (2081), 20160076. http://dx.doi.org/10.1098/rsta.2016.0076.

Chavez, F.P., Bertrand, A., Guevara-Carrasco, R., Soler, P., Csirke, J., 2008. The northern Humboldt Current System: brief history, present status and a view towards the future. Prog. Oceanogr. 79 (2-4), 95-105. http://dx.doi.org/10.1016/j.pocean.2008.10.012.

Chung, Y.-C., 1974. Radium-226 and Ra-Ba relationships in Antarctic and Pacific waters. Earth Planet. Sci. Lett. 23 (1), 125-135. http://dx.doi.org/10.1016/0012-821X(74) 90039-9.

Chung, Y., 1980. Radium-barium-silica correlations and a two-dimensional radium model for the world ocean. Earth Planet. Sci. Lett. 49 (2), 309-318. http://dx.doi.org/10. 1016/0012-821X(80)90074-6.

Chung, Y., Craig, H., 1973. Radium-226 in the eastern equatorial Pacific. Earth Planet. Sci. Lett. 17, 306-318. http://dx.doi.org/10.1016/0012-821X(73)90195-7.

Chung, Y., Craig, H., 1980. ${ }^{226}$ Ra in the Pacific Ocean. Earth Planet. Sci. Lett. 49 (2), 267-292. http://dx.doi.org/10.1016/0012-821X(80)90072-2.

Cochran, J.K., 1980. The flux of ${ }^{226}$ Ra from deep-sea sediments. Earth Planet. Sci. Lett. 49 (2), 381-392. http://dx.doi.org/10.1016/0012-821X(80)90080-1.

Codispoti, L.A., Yoshinari, T., Devol, A.H., 2005. Suboxic respiration in the oceanic water column. In: Respiration in Aquatic Ecosystems, pp. 225-247.

Cole, S.T., Wortham, C., Kunze, E., Owens, W.B., 2015. Eddy stirring and horizontal diffusivity from Argo float observations: Geographic and depth variability. Geophys. Res. Lett. 42http://dx.doi.org/10.1002/2015GL063827. 2015GL063827.

Craig, H., 1972. The Geosecs program: 1970-1971. Earth Planet. Sci. Lett. 16, 47-49. http://dx.doi.org/10.1016/0012-821X(72)90235-X.

Cravatte, S., Kessler, W.S., Marin, F., 2012. Intermediate zonal jets in the tropical Pacific Ocean observed by Argo floats. J. Phys. Oceanogr. 42 (9), 1475-1485. http://dx.doi. org/10.1175/JPO-D-11-0206.1.

Czeschel, R., Stramma, L., Weller, R.A., Fischer, T., 2015. Circulation, eddies, oxygen, and nutrient changes in the eastern tropical South Pacific Ocean. Ocean Sci. 11, 455-470. http://dx.doi.org/10.5194/os-11-455-2015.

Dale, A.W., Nickelsen, L., Scholz, F., Hensen, C., Oschlies, A., Wallmann, K., 2015. A revised global estimate of dissolved iron fluxes from marine sediments. Glob. Biogeochem. Cycles 29 (5) (2014GB005017). http://dx.doi.org/10.1002/ 2014 GB005017.

DeVries, T., Primeau, F., 2011. Dynamically and observationally constrained estimates of water-mass distributions and ages in the Global Ocean. J. Phys. Oceanogr. 41 (12), 2381-2401. http://dx.doi.org/10.1175/JPO-D-10-05011.1.

Dulaiova, H., Ardelan, M.V., Henderson, P.B., Charette, M.A., 2009. Shelf-derived iron inputs drive biological productivity in the southern Drake Passage. Global Biogeochem. Cycles 23, GB4014. http://dx.doi.org/10.1029/2008GB003406.

Elrod, V.A., Berelson, W.M., Coale, K.H., Johnson, K.S., 2004. The flux of iron from continental shelf sediments: a missing source for global budgets. Geophys. Res. Lett. 31 (12), L12307. http://dx.doi.org/10.1029/2004GL020216.

Fiedler, P.C., Talley, L.D., 2006. Hydrography of the eastern tropical Pacific: a review. Prog. Oceanogr. 69 (2-4), 143-180. http://dx.doi.org/10.1016/j.pocean.2006.03. 008 .

Fitzsimmons, J.N., Boyle, E.A., Jenkins, W.J., 2014. Distal transport of dissolved hydrothermal iron in the deep South Pacific Ocean. PNAS 111 (47), 16654-16661. http:// dx.doi.org/10.1073/pnas.1418778111.

Gonneea, M.E., Mulligan, A.E., Charette, M.A., 2013. Climate-driven sea level anomalies modulate coastal groundwater dynamics and discharge. Geophys. Res. Lett. 40 (11), 2701-2706. http://dx.doi.org/10.1002/grl.50192.

Hammond, D.E., Marton, R.A., Berelson, W.M., Ku, T.-L., 1990. Radium 228 distribution and mixing in San Nicolas and San Pedro Basins, southern California Borderland. J. Geophys. Res. 95 (C3), 3321-3335. http://dx.doi.org/10.1029/JC095iC03p0332.

Hanfland, C., 2002. Radium-226 and Radium-228 in the Atlantic Sector of the Southern Ocean. (Thesis) Alfred Wegener Institute, Bremerhaven Allemagne.

Hatta, M., Measures, C.I., Wu, J., Roshan, S., Fitzsimmons, J.N., Sedwick, P., Morton, P., 2015. An overview of dissolved Fe and Mn distributions during the 2010-2011 U.S. GEOTRACES north Atlantic cruises: GEOTRACES GA03. Deep-Sea Res. II Top. Stud. Oceanogr. 116, 117-129. http://dx.doi.org/10.1016/j.dsr2.2014.07.005.

Hawco, N.J., Ohnemus, D.C., Resing, J.A., Twining, B.S., Saito, M.A., 2016. A dissolved cobalt plume in the oxygen minimum zone of the eastern tropical South Pacific. Biogeosciences 13 (20), 5697-5717. http://dx.doi.org/10.5194/bg-13-5697-2016. (2016).

Heller, M.I., Lam, P.J., Moffet, J.W., Till, C.P., Lee, J-M., Toner, B.M., Marcus, M.A., (2017) submitted to Geochemicica et Cosmochimica Acta. Accumulation of Fe oxides in the Peruvian oxygen deficient zone implies non-oxygen dependent Fe oxidation (in review).

Henderson, P.B., Morris, P.J., Moore, W.S., Charette, M.A., 2013. Methodological advances for measuring low-level radium isotopes in seawater. J. Radioanal. Nucl. Chem. 296 (1), 357-362. http://dx.doi.org/10.1007/s10967-012-2047-9.

von der Heyden, B.P., Roychoudhury, A.N., 2015. A review of colloidal iron partitioning and distribution in the open ocean. Mar. Chem. 177 (Part 1), 9-19. http://dx.doi.org/ 10.1016/j.marchem.2015.05.010.

Huettel, M., Berg, P., Kostka, J.E., 2014. Benthic exchange and biogeochemical cycling in permeable sediments. Annu. Rev. Mar. Sci. 6, 23-51. http://dx.doi.org/10.1146/ annurev-marine-051413-012706.
Huh, C.-A., Ku, T.-L., 1998. A 2D section of ${ }^{228} \mathrm{Ra}$ and ${ }^{226} \mathrm{Ra}$ in the Northeast Pacific. Oceanol. Acta 21 (4), 533-542. http://dx.doi.org/10.1016/S0399-1784(98)80036-4. van Hulten, M., Dutay, J.-C., Middag, R., de Baar, H., Roy-Barman, M., Gehlen, M., Tagliabue, A., Sterl, A., 2016. Manganese in the world ocean: a first global model. Biogeosci. Discuss. 1-38. http://dx.doi.org/10.5194/bg-2016-282.

Hunter, K.A., Boyd, P.W., 2007. Iron-binding ligands and their role in the ocean biogeochemistry of iron. Environ. Chem. 4 (4), 221-232. http://dx.doi.org/10.1071/ EN07012.

Hutchins, D.A., Hare, C.E., Weaver, R.S., Zhang, Y., Firme, G.F., DiTullio, G.R., Alm, M.B., Riseman, S.F., Maucher, J.M., Geesey, M.E., Trick, C.G., Smith, G.J., Rue, E.L., Conn, J., Bruland, K.W., 2002. Phytoplankton iron limitation in the Humboldt Current and Peru Upwelling. Limnol. Oceanogr. 47 (4), 997-1011.

IRN ENSO Forecast: International Research Institute for Climate and Society, 2013 November. Quick look. [online] Available from: http://iri.columbia.edu/ourexpertise/climate/forecasts/enso/2013-november-quick-look/.

Jahnke, R.A., 2010. Global synthesis1. In: Liu, P.K.-K., Atkinson, P.L., Quiñones, P.R., Talaue-McManus, D.L. (Eds.), Carbon and Nutrient Fluxes in Continental Margins. Global Change - The IGBP Series Springer, Berlin Heidelberg, pp. 597-615. http:// dx.doi.org/10.1007/978-3-540-92735-8_16.

Jeandel, C., Peucker-Ehrenbrink, B., Jones, M.T., Pearce, C.R., Oelkers, E.H., Godderis, Y., Lacan, F., Aumont, O., Arsouze, T., 2011. Ocean margins: the missing term in oceanic element budgets? Eos. Trans. AGU 92 (26), 217-218. http://dx.doi.org/10.1029/ $2011 \mathrm{EO} 260001$.

Jickells, T.D., Spokes, L.J., 2001. Atmospheric iron inputs to the oceans. In: The Biogeochemistry of Iron in Seawater. John Wiley, Hoboken, N.J, pp. 85-118.

Jickells, T.D., An, Z.S., Andersen, K.K., Baker, A.R., Bergametti, G., Brooks, N., Cao, J.J., Boyd, P.W., Duce, R.A., Hunter, K.A., Kawahata, H., Kubilay, N., laRoche, J., Liss, P.S., Mahowald, N., Prospero, J.M., Ridgwell, A.J., Tegen, I., Torres, R., 2005. Global iron connections between desert dust, ocean biogeochemistry, and climate. Science 308 (5718), 67-71. http://dx.doi.org/10.1126/science.1105959.

John, S.G., Helgoe, J., Townsend, E., Weber, T., DeVries, T., Tagliabue, A., Moore, K., Lam, P., Marsay, C., Till, C., 2017. Biogeochemical cycling of Fe and Fe stable isotopes in the Eastern Tropical South Pacific. in this issue.

Johnson, K.S., Coale, K.H., Berelson, W.M., Michael Gordon, R., 1996. On the formation of the manganese maximum in the oxygen minimum. Geochimica et Cosmochimica Acta 60, 1291-1299. http://dx.doi.org/10.1016/0016-7037(96)00005-1.

Johnson, K.S., Gordon, R.M., Coale, K.H., 1997. What controls dissolved iron concentrations in the world ocean? Mar. Chem. 57 (3), 137-161. http://dx.doi.org/10. 1016/S0304-4203(97)00043-1.

Johnson, K.S., Chavez, F.P., Friederich, G.E., 1999. Continental-shelf sediment as a primary source of iron for coastal phytoplankton. Nature 398 (6729), 697-700. http:// dx.doi.org/10.1038/19511.

Karstensen, J., Stramma, L., Visbeck, M., 2008. Oxygen minimum zones in the eastern tropical Atlantic and Pacific oceans. Prog. Oceanogr. 77 (4), 331-350. http://dx.doi. org/10.1016/j.pocean.2007.05.009.

Kaufman, A., Trier, R.M., Broecker, W.S., Feely, H.W., 1973. Distribution of ${ }^{228}$ Ra in the world ocean. J. Geophys. Res. 78 (36), 8827-8848. http://dx.doi.org/10.1029/ JC078i036p08827.

Kelly, R.P., Moran, S.B., 2002. Seasonal changes in groundwater input to a well-mixed estuary estimated using radium isotopes and implications for coastal nutrient budgets. Limnol. Oceanogr. 47 (6), 1796-1807. http://dx.doi.org/10.4319/1o.2002.47.6. 1796.

Kessler, W.S., 2006. The circulation of the eastern tropical Pacific: a review. Prog. Oceanogr. 69 (2-4), 181-217. http://dx.doi.org/10.1016/j.pocean.2006.03.009.

Key, R.M., Brewer, R.L., Stockwell, J.H., Guinasso Jr., N.L., Schink, D.R., 1979. Some improved techniques for measuring radon and radium in marine sediments and in seawater. Mar. Chem. 7 (3), 251-264. http://dx.doi.org/10.1016/0304-4203(79) 90042-2.

Kipp, L.E., Sanial V., Henderson P.B., van Beek P., Reyss J-L, Hammond D.E., Moore W.S., Charette M.A., (in this issue) 2017. Radium isotopes as tracers of hydrothermal inputs and neutrally buoyant dynamics in the deep ocean.

Khatiwala, S., Primeau, F., Holzer, M., 2012. Ventilation of the deep ocean constrained with tracer observations and implications for radiocarbon estimates of ideal mean age. Earth Planet. Sci. Lett. 325-326, 116-125. http://dx.doi.org/10.1016/j.epsl. 2012.01.038.

Knauss, K.G., Ku, T.-L., Moore, W.S., 1978. Radium and thorium isotopes in the surface waters of the East Pacific and coastal Southern California. Earth Planet. Sci. Lett. 39 (2), 235-249. http://dx.doi.org/10.1016/0012-821X(78)90199-1.

Koczy, F.F., 1958. Natural radium as a tracer in the ocean. In: Second U.N. International Conference Peaceful Uses Atom Energy, Geneva, pp. 351-357.

Krissek, L.A., Scheidegger, K.F., Kulm, L.D., 1980. Surface sediments of the Peru-Chile continental margin and the Nazca plate. Geol. Soc. Am. Bull. 91, 321-331. http://dx. doi.org/10.1130/0016-7606(1980)91<321:SSOTPC > 2.0.CO;2.

Ku, T.-L., Lin, M.-C., 1976. ${ }^{226}$ Ra distribution in the Antarctic Ocean. Earth Planet. Sci. Lett. 32 (2), 236-248. http://dx.doi.org/10.1016/0012-821X(76)90064-9.

Ku, T.L., Li, Y.H., Mathieu, G.G., Wong, H.K., 1970. Radium in the Indian-Antarctic Ocean south of Australia. J. Geophys. Res. 75 (27), 5286-5292. http://dx.doi.org/10.1029/ JC075i027p05286.

Kwon, E.Y., Kim, G., Primeau, F., Moore, W.S., Cho, H.-M., DeVries, T., Sarmiento, J.L., Charette, M.A., Cho, Y.-K., 2014. Global estimate of submarine groundwater discharge based on an observationally constrained radium isotope model. Geophys. Res. Lett. 41 (23) (2014GL061574). http://dx.doi.org/10.1002/2014GL061574.

Lam, P.J., Bishop, J.K.B., 2008. The continental margin is a key source of iron to the HNLC North Pacific Ocean. Geophys. Res. Lett. 35 (7), L07608. http://dx.doi.org/10. 1029/2008GL033294.

Lam, P.J., Lee, J-M., Heller, M.I., (in this issue) 2017. Size-fractionated distributions of 
particulate trace elements from the U.S. GEOTRACES Eastern Pacific Zonal Transect (GP16).

Lampitt, R.S., Raine, R.C.T., Billett, D.S.M., Rice, A.L., 1995. Material supply to the European continental slope: a budget based on benthic oxygen demand and organic supply. Deep-Sea Res. I Oceanogr. Res. Pap. 42 (11), 1865-1880. http://dx.doi.org/ 10.1016/0967-0637(95)00084-4.

Landing, W.M., Bruland, K.W., 1987. The contrasting biogeochemistry of iron and manganese in the Pacific Ocean. Geochim. Cosmochim. Acta 51 (1), 29-43. http://dx.doi. org/10.1016/0016-7037(87)90004-4.

Lee J-M., Heller M.I., Lam P.J., (in this issue) 2017. Size-fractionated distributions of particulate trace elements from the U.S. GEOTRACES Eastern Pacific Zonal Transect (GP16).

Lentz, S.J., Chapman, D.C., 2004. The importance of nonlinear cross-shelf momentum flux during wind-driven coastal upwelling. J. Phys. Oceanogr. 34 (11), 2444-2457. http://dx.doi.org/10.1175/JPO2644.1.

Letscher, R.T., Primeau, F., Moore, J.K., 2016. Nutrient budgets in the subtropical ocean gyres dominated by lateral transport. Nat. Geosci. 9 (11), 815-819. http://dx.doi. org/10.1038/ngeo2812.

Li, Y.-H., Feely, H.W., Toggweiler, J.R., 1980. ${ }^{228}$ Ra and ${ }^{228}$ Th concentrations in GEOSECS Atlantic surface waters. Deep-Sea Res. I Oceanogr. Res. Pap. 27A (545-555).

Lopez, G.I., Marcantonio, F., Lyle, M., Lynch-Stieglitz, J., 2015. Dissolved and particulate 230Th-232Th in the Central Equatorial Pacific Ocean: Evidence for far-field transport of the East Pacific Rise hydrothermal plume. Earth Planet. Sci. Lett. 431, 87-95. http://dx.doi.org/10.1016/j.epsl.2015.09.019.

Madison, A.S., Tebo, B.M., Mucci, A., Sundby, B., Luther, G.W., 2013. Abundant porewater Mn(III) is a major component of the sedimentary redox system. Science 341 (6148), 875-878. http://dx.doi.org/10.1126/science.1241396.

McLennan, S.M., 2001. Relationships between the trace element composition of sedimentary rocks and upper continental crust. Geochem. Geophys. Geosyst. 2 (4), 1021. http://dx.doi.org/10.1029/2000GC000109.

McManus, J., Berelson, W.M., Severmann, S., Johnson, K.S., Hammond, D.E., Roy, M., Coale, K.H., 2012. Benthic manganese fluxes along the Oregon-California continental shelf and slope. Cont. Shelf Res. 43, 71-85. http://dx.doi.org/10.1016/j.csr.2012.04. 016.

Milliman, J.D., Farnsworth, K.L., 2011. River Discharge to the Coastal Ocean.

Moffett, J.W., 1997. The importance of microbial Mn oxidation in the upper ocean: a comparison of the Sargasso Sea and equatorial Pacific. Deep-Sea Res. I Oceanogr. Res. Pap. 44 (8), 1277-1291. http://dx.doi.org/10.1016/S0967-0637(97)00032-0.

Moore, W.S., 1969a. Measurement of $\mathrm{Ra}^{228}$ and $\mathrm{Th}^{228}$ in sea water. J. Geophys. Res. 74 (2), 694-704. http://dx.doi.org/10.1029/JB074i002p00694.

Moore, W.S., 1969b. Oceanic concentrations of ${ }^{228}$ Radium. Earth Planet. Sci. Lett. 6 (6), 437-446. http://dx.doi.org/10.1016/0012-821X(69)90113-7.

Moore, W.S., 1984. Radium isotope measurements using germanium detectors. Nucl. Inst. Methods Phys. Res. A 223 (2-3), 407-411. http://dx.doi.org/10.1016/01675087(84)910683-5.

Moore, W.S., 1996. Large groundwater inputs to coastal waters revealed by ${ }^{226} \mathrm{Ra}$ en richments. Nature 380 (6575), 612-614. http://dx.doi.org/10.1038/380612a0.

Moore, W.S., 1999. The subterranean estuary: a reaction zone of ground water and sea water. Mar. Chem. 65 (1-2), 111-125. http://dx.doi.org/10.1016/S0304-4203(99) 00014-6.

Moore, W.S., 2000. Determining coastal mixing rates using radium isotopes. Cont. Shelf Res. 20 (15), 1993-2007. http://dx.doi.org/10.1016/S0278-4343(00)00054-6.

Moore, W.S., 2007. Seasonal distribution and flux of radium isotopes on the southeastern U.S. continental shelf. J. Geophys. Res. 112 (C10), C10013. http://dx.doi.org/10. 1029/2007JC004199.

Moore, W.S., 2008. Fifteen years experience in measuring ${ }^{224} \mathrm{Ra}$ and ${ }^{223} \mathrm{Ra}$ by delayedcoincidence counting. Mar. Chem. 109 (3-4), 188-197. http://dx.doi.org/10.1016/j. marchem.2007.06.015.

Moore, W.S., 2015. Inappropriate attempts to use distributions of ${ }^{228} \mathrm{Ra}$ and ${ }^{226} \mathrm{Ra}$ in coastal waters to model mixing and advection rates. Cont. Shelf Res. 105, 95-100. http://dx.doi.org/10.1016/j.csr.2015.05.014.

Moore, J.K., Braucher, O., 2008. Sedimentary and mineral dust sources of dissolved iron to the world ocean. Biogeosciences 5 (3), 631-656.

Moore, W.S., Dymond, J., 1991. Fluxes of ${ }^{226} \mathrm{Ra}$ and barium in the Pacific Ocean: the importance of boundary processes. Earth Planet. Sci. Lett. 107 (1), 55-68. http://dx. doi.org/10.1016/0012-821X(91)90043-H.

Moore, W.S., Shaw, T.J., 2008. Fluxes and behavior of radium isotopes, barium, and uranium in seven Southeastern US rivers and estuaries. Mar. Chem. 108 (3-4), 236-254. http://dx.doi.org/10.1016/j.marchem.2007.03.004.

Morel, F.M.M., Price, N.M., 2003. The biogeochemical cycles of trace metals in the oceans. Science 300 (5621), 944-947. http://dx.doi.org/10.1126/science.1083545

Noble, A.E., Lamborg, C.H., Ohnemus, D.C., Lam, P.J., Goepfert, T.J., Measures, C.I., Frame, C.H., Casciotti, K.L., DiTullio, G.R., Jennings, J., Saito, M.A., 2012. Basinscale inputs of cobalt, iron, and manganese from the Benguela-Angola front to the South Atlantic Ocean. Limnol. Oceanogr. 57 (4), 989-1010. http://dx.doi.org/10. 4319/10.2012.57.4.0989.

Noffke, A., Hensen, C., Sommer, S., Scholz, F., Bohlen, L., Mosch, T., Graco, M., Wallmann, K., 2012. Benthic iron and phosphorus fluxes across the Peruvian oxygen minimum zone. Limnol. Oceanogr. 57 (3), 851-867. http://dx.doi.org/10.4319/lo. 2012.57.3.0851.

Ohnemus, D.C., Rauschenberg, S., Cutter, G.A., Fitzsimmons, J.N., Sherrell, R.M., Twining, B.S., 2016. Elevated trace metal content of prokaryotic communities associated with marine oxygen deficient zones. Limnol. Oceanogr. 00-00. http://dx.doi org/10.1002/lno.10363.

Okubo, A., 1971. Oceanic diffusion diagrams. Deep-Sea Res. Oceanogr. Abstr. 18 (8),
789-802. http://dx doi.org/10.1016/0011-7471(71)90046-5.

Paulmier, A., Ruiz-Pino, D., 2009. Oxygen minimum zones (OMZs) in the modern ocean Prog. Oceanogr. 80 (3-4), 113-128. http://dx.doi.org/10.1016/j.pocean.2008.08. 001

Pegliasco, C., Chaigneau, A., Morrow, R., 2015. Main eddy vertical structures observed in the four major eastern boundary upwelling systems. J. Geophys. Res. Oceans 120 (9), 6008-6033. http://dx.doi.org/10.1002/2015JC010950.

Pennington, J.T., Mahoney, K.L., Kuwahara, V.S., Kolber, D.D., Calienes, R., Chavez, F.P., 2006. Primary production in the eastern tropical Pacific: a review. Prog. Oceanogr. 69 (2-4), 285-317. http://dx.doi.org/10.1016/j.pocean.2006.03.012.

Penven, P., Echevin, V., Pasapera, J., Colas, F., Tam, J., 2005. Average circulation, seasonal cycle, and mesoscale dynamics of the Peru Current System: a modeling approach. J. Geophys. Res. 110, C10021. http://dx.doi.org/10.1029/2005JC002945.

Peters, B., Casciotti, K., Jenkins, W. J., Swift, J., German, C., Moffet, J., Cutter, G., Brzezinski, M. A., (in this issue) 2017. Water mass analysis of the 2013 US GEOTRACES Eastern Pacific Zonal Transect (GP16).

Peterson, R.N., Burnett, W.C., Dimova, N., Santos, I.R., 2009. Comparison of measurement methods for radium-226 on manganese-fiber. Limnol. Oceanogr. Methods 7 (2), 196-205. http://dx.doi.org/10.4319/lom.2009.7.196.

Ramage, C.S., 1975. Preliminary discussion of the meteorology of the - El Niño. Bull. Am. Meteorol. Soc. 56 (2), 234-242. http://dx.doi.org/10.1175/1520-0477(1975) $056<0234$ :PDOTMO > 2.0.CO;2.

Reid, J.L., 1997. On the total geostrophic circulation of the pacific ocean: flow patterns, tracers and transports. Prog. Oceanogr. 39, 263-352.

Resing, J.A., Sedwick, P.N., German, C.R., Jenkins, W.J., Moffett, J.W., Sohst, B.M., Tagliabue, A., 2015. Basin-scale transport of hydrothermal dissolved metals across the South Pacific Ocean. Nature 523 (7559), 200-203. http://dx.doi.org/10.1038/ nature14577.

Reyss, J.-L., Schmidt, S., Legeleux, F., Bonté, P., 1995. Large, low background well-type detectors for measurements of environmental radioactivity. Nucl. Instrum. Methods Phys. Res., Sect. A 357 (2-3), 391-397. http://dx.doi.org/10.1016/0168-9002(95) 00021-6.

Robinson, C., Gibbes, B., Li, L., 2006. Driving mechanisms for groundwater flow and salt transport in a subterranean estuary. Geophys. Res. Lett. 33 (3), L03402. http://dx. doi.org/10.1029/2005GL025247.

Saito, M.A., Moffett, J.W., DiTullio, G.R., 2004. Cobalt and nickel in the Peru upwelling region: a major flux of labile cobalt utilized as a micronutrient. Glob. Biogeochem. Cycles 18 (4), GB4030. http://dx.doi.org/10.1029/2003GB002216. (2004).

Sarmiento, J.L., Rooth, C.G.H., 1980. A comparison of vertical and isopycnal mixing models in the deep sea based on radon 222 measurements. J. Geophys. Res. 85 (C3), 1515-1518. http://dx.doi.org/10.1029/JC085iC03p01515.

Sarmiento, J.L., Rooth, C.G.H., Broecker, W.S., 1982. Radium 228 as a tracer of basin wide processes in the abyssal ocean. J. Geophys. Res. 87 (C12), 9694-9698. http:// dx.doi.org/10.1029/JC087iC12p09694.

SCOR Working Group, 2007. GEOTRACES - An international study of the global marine biogeochemical cycles of trace elements and their isotopes. Chem. Erde-Geochem. 67, 85-131. http://dx.doi.org/10.1016/j.chemer.2007.02.001.

Scheidegger, K.F., Krissek, L.A., 1982. Dispersal and deposition of eolian and fluvial sediments off Peru and northern Chile. Geol. Soc. Am. Bull. 93 (2), 150-162. http://dx. doi.org/10.1130/0016-7606(1982)93<150:DADOEA > 2.0.CO;2.

Scheidegger, K.F., Krissek, L.A., 1983. Zooplankton and Nekton: Natural Barriers to the Seaward Transport of Suspended Terrigenous Particles Off Peru. pp. 303-333. http:// dx.doi.org/10.1007/978-1-4615-6651-9 16.

Scholl, D.W., Christensen, M.N., Huene, R.V., Marlow, M.S., 1970. Peru-Chile trench sediments and sea-floor spreading. Geol. Soc. Am. Bull. 81 (5), 1339-1360. http://dx. doi.org/10.1130/0016-7606(1970)81[1339:PTSASS]2.0.CO;2.

Scholz, F., Hensen, C., Noffke, A., Rohde, A., Liebetrau, V., Wallmann, K., 2011. Early diagenesis of redox-sensitive trace metals in the Peru upwelling area - response to ENSO-related oxygen fluctuations in the water column. Geochim. Cosmochim. Acta 75 (22), 7257-7276. http://dx.doi.org/10.1016/j.gca.2011.08.007.

Scholz, F., McManus, J., Mix, A.C., Hensen, C., Schneider, R.R., 2014. The impact of ocean deoxygenation on iron release from continental margin sediments. Nat. Geosci. 7 (6), 433-437. http://dx.doi.org/10.1038/ngeo2162.

Scholz, F., Löscher, C.R., Fiskal, A., Sommer, S., Hensen, C., Lomnitz, U., Wuttig, K., Göttlicher, J., Kossel, E., Steininger, R., Canfield, D.E., 2016. Nitrate-dependent iron oxidation limits iron transport in anoxic ocean regions. Earth Planet. Sci. Lett. 454, 272-281. http://dx.doi.org/10.1016/j.epsl.2016.09.025.

Sedwick, P.N., Sohst, B.M., Ussher, S.J., Bowie, A.R., 2015. A zonal picture of the water column distribution of dissolved iron(II) during the U.S. GEOTRACES North Atlantic transect cruise (GEOTRACES GA03). Deep-Sea Res. II Top. Stud. Oceanogr. 116, 166-175. http://dx.doi.org/10.1016/j.dsr2.2014.11.004.

Shelley, R.U., Sedwick, P.N., Bibby, T.S., Cabedo-Sanz, P., Church, T.M., Johnson, R.J., Macey, A.I., Marsay, C.M., Sholkovitz, E.R., Ussher, S.J., Worsfold, P.J., Lohan, M.C., 2012. Controls on dissolved cobalt in surface waters of the Sargasso Sea: comparisons with iron and aluminum. Glob. Biogeochem. Cycles 26 (2), GB2020. http://dx.doi. org/10.1029/2011GB004155.

Stumm, W., Morgan, J.J., 1996. Aquatic Chemistry: Chemical Equilibria and Rates in Natural Waters. John Wiley \& Sons.

Sunda, W.G., Huntsman, S.A., 1988. Effect of sunlight on redox cycles of manganese in the southwestern Sargasso Sea. Deep Sea Res. Part A 35 (8), 1297-1317. http://dx. doi.org/10.1016/0198-0149(88)90084-2.

Sunda, W.G., Huntsman, S.A., 1995a. Iron uptake and growth limitation in oceanic and coastal phytoplankton. Mar. Chem. 50 (1), 189-206. http://dx.doi.org/10.1016/ 0304-4203(95)00035-P.

Sunda, W.G., Huntsman, S.A., 1995b. Cobalt and zinc interreplacement in marine phytoplankton: biological and geochemical implications. Oceanogr. Lit. Rev. 8 (43), 781. 
Sunda, W.G., Huntsman, S.A., Harvey, G.R., 1983. Photoreduction of manganese oxides in seawater and its geochemical and biological implications. Nature 301 (5897), 234-236. http://dx.doi.org/10.1038/301234a0.

Tagliabue, A., Sallée, J.-B., Bowie, A.R., Lévy, M., Swart, S., Boyd, P.W., 2014. Surfacewater iron supplies in the Southern Ocean sustained by deep winter mixing. Nat. Geosci. 7 (4), 314-320. http://dx.doi.org/10.1038/ngeo2101.

Taylor, S.R., McLennan, S.M., 1985. The Continental Crust: Its Composition and Evolution. Blackwell Scientific Publications, Oxford, Boston.

Thomsen, S., Kanzow, T., Colas, F., Echevin, V., Krahmann, G., Engel, A., 2016. Do submesoscale frontal processes ventilate the oxygen minimum zone off Peru? Geophys. Res. Lett. 43 (2016GL070548). http://dx.doi.org/10.1002/2016GL070548.

van Beek, P., François, R., Conte, M., Reyss, J.-L., Souhaut, M., Charette, M., 2007. ${ }^{228} \mathrm{Ra}$ / $2^{26} \mathrm{Ra}$ and ${ }^{226} \mathrm{Ra} / \mathrm{Ba}$ ratios to track barite formation and transport in the water column. Geochim. Cosmochim. Acta 71 (1), 71-86. http://dx.doi.org/10.1016/j.gca. 2006.07.041.

van Beek, P., Bourquin, M., Reyss, J.-L., Souhaut, M., Charette, M.A., Jeandel, C., 2008. Radium isotopes to investigate the water mass pathways on the Kerguelen Plateau (Southern Ocean). Deep-Sea Res. II Top. Stud. Oceanogr. 55 (5-7), 622-637. http:// dx.doi.org/10.1016/j.dsr2.2007.12.025.

Vedamati, J., Goepfert, T., Moffett, J.W., 2014. Iron speciation in the eastern tropical South Pacific oxygen minimum zone off Peru. Limnol. Oceanogr. 59 (6), 1945-1957. http://dx.doi.org/10.4319/1o.2014.59.6.1945.

Vedamati, J., Chan, C., Moffett, J.W., 2015. Distribution of dissolved manganese in the Peruvian upwelling and oxygen minimum zone. Geochim. Cosmochim. Acta 156, 222-240. http://dx.doi.org/10.1016/j.gca.2014.10.026.

Viers, J., Dupré, B., Gaillardet, J., 2009. Chemical composition of suspended sediments in World Rivers: New insights from a new database. Sci. Total Environ. 407, 853-868. http://dx.doi.org/10.1016/j.scitotenv.2008.09.053.

Walsh, J.P., Nittrouer, C.A., 1999. Observations of sediment flux to the Eel continental slope, northern California. Mar. Geol. 154 (1-4), 55-68. http://dx.doi.org/10.1016/ S0025-3227(98)00103-0.

Whalen, C.B., Talley, L.D., MacKinnon, J.A., 2012. Spatial and temporal variability of global ocean mixing inferred from Argo profiles. Geophys. Res. Lett. 39, L18612. http://dx.doi.org/10.1029/2012GL053196.

Windom, H.L, Moore, W.S, Niencheski, L.F.H., Jahnke, R.A., 2006. Submarine groundwater discharge: a large, previously unrecognized source of dissolved iron to the South Atlantic Ocean. Mar. Chem. 102 (3-4), 252-266. http://dx.doi.org/10.1016/j. marchem.2006.06.016.

Yamada, M., Nozaki, Y., 1986. Radium isotopes in coastal and open ocean surface waters of the Western North Pacific. Mar. Chem. 19 (4), 379-389. http://dx.doi.org/10. 1016/0304-4203(86)90057-5. 